\title{
Instrument policy mix and firm size: is there complementarity between $R \& D$ subsidies and $R \& D$ tax credits?
}

\author{
Tea Petrin ${ }^{1}$ - Dragana Radicic ${ }^{2}$ (D)
}

Accepted: 17 November 2021 / Published online: 7 December 2021

(c) The Author(s) 2021

\begin{abstract}
Nowadays, a rising number of evaluations investigates a multifaceted concept of the policy mix. Our study specifically focuses on the mix of two most frequently used supply-side instruments-R\&D subsidies and R\&D tax credits. Drawing on the longitudinal sample of Spanish manufacturing firms, we investigate whether there is a complementary interaction between these policy instruments with respect to product and process innovations. Moreover, by employing a dynamic random-effects probit estimator, we account for the persistence of innovation and endogeneity of public support. The results, that are separately estimated for SMEs and large firms, uniformly show evidence of no interplay between two policy instruments either in SMEs or large firms. However, among factors that influence the propensity to product and process innovations, by far, the largest effect is generated by true state dependence. These findings provide some policy implications for fostering product and process innovations in the long run.
\end{abstract}

Keywords Instrument policy mix $\cdot$ R\&D subsidies $\cdot R \& D$ tax credits $\cdot$ Persistence of innovation $\cdot$ SMEs $\cdot$ Spanish manufacturing

JEL Classification $\mathrm{O} 32 \cdot \mathrm{O} 380$

\section{Introduction}

This study investigates the instrument policy mix between R\&D subsidies and R\&D tax credits in the context of output additionality. In the last few decades, the evolution of contemporary policies for fostering and stimulating innovation has resulted in an increasingly

Dragana Radicic

dradicic@lincoln.ac.uk

Tea Petrin

tea.petrin@ef.uni-lj.si

1 School of Economics and Business, University of Ljubljana, Kongresni trg 12, 1000 Ljubljana, Slovenia

2 Department of Accounting, Finance and Economics, Lincoln International Business School, University of Lincoln, Brayford Pool, Lincoln LN6 7TS, UK 
complex mix of policies and programmes. For instance, the INNO-policy Trendchart database of innovation policy measures in Europe has reached more than 1000 measures in 2009, compared to less than 200 in 1995 (European Commission, 2009). Governments direct large sums of public funds towards expanding the base of scientific and technological knowledge to reduce uncertainty, to substitute inefficient markets by sharing risks and costs and to devise ways to overcome inappropriability issues (Cunningham, Edler, et al., 2016; Cunningham, Gök, et al., 2016). A variety of tax incentives and R\&D subsidy measures were introduced with the intention of encouraging private firms to undertake $R \& D$ projects at their own expense (David et al., 2000). During the 2000-2013 period, for example, government financial support instruments to promote $R \& D$ have accounted for nearly $70 \%$ of all R\&D cost performed in OECD countries in the form of grants, purchase of R\&D services and R\&D tax incentives (Appelt et al., 2016).

The main reason for this increased complexity is the co-existence of two policy rationales; alongside the neoclassical market-failure rationale, an evolutionary-systemic rationale has emerged as a complementary basis for justifying public intervention in the domain of innovation. Whilst the market-failure rationale emphasizes the importance of investing in science and technology, the evolutionary-systemic rationale focuses on the interaction of organizations and institutions within systems of innovation. A direct consequence of the widening of policy rationales is the introduction and implementation of a large number of policy instruments. Besides traditional, hard innovation policy instruments, stemming from the neoclassical, market-failure approach (such as R\&D subsidies and R\&D tax credits), a set of soft and non-coercive policy instruments has been implemented, reflecting the proliferation of evolutionary, systemic policies. Examples of soft instruments are standards, best practices, codes of conduct, public-private partnerships based on cost-sharing etc. These instruments are increasingly used since the 1990s, and most recently are focused on the establishment and maintenance of innovation networks. Freitas (2007) identified more than 80 soft instruments implemented in the UK since the 1990s. Therefore, the evolution of policy rationales (from the market failure to systemic failure rationale) encompassed the implementation of new instruments but existing instruments were seldom abolished (Boekholt, 2010; Magro \& Wilson, 2013). That is why nowadays a large number of public measures (e.g. hard and soft instruments, supply-side and demand-side instruments) exists. In summing up, the innovation policy domain is characterized by the existence of complementary policy rationales, accompanied by a complementary mix of policy instruments. To reflect the widening of policy rationales and a proliferation of various policy instruments, the concept of the innovation policy mix has recently emerged (Flanagan et al., 2011; Magro \& Wilson, 2013, 2018; Meissner \& Kergroach, 2021).

The emergence of the innovation policy mix is accompanied by the emerging need for systemic evaluation, which takes into account interactions and interdependencies of modern innovation policies. Increasing concern with value for money, together with a growing policy complexity are driving increased interest in evaluation of the innovation policy mix on the part of policy makers (Meissner \& Kergroach, 2021). Scholars and evaluators of innovation policies have only recently put forth the necessity for the systemic evaluation of innovation policies (Arnold, 2004; Flanagan et al., 2011; Magro \& Wilson, 2013) given that insights on the innovation policy mix are mainly theoretical and rhetorical (Meissner \& Kergroach, 2021).

In this study, we investigate the interaction between two most frequently used supplyside policy measures-R\&D subsidies and R\&D tax credits on product and process innovations in Spanish manufacturing firms. Both policy instruments have distinctive objectives which are complementary (Elschner et al., 2011; Tassey, 2007). Concerning R\&D 
tax incentives, their main advantage is that they are market neutral, which means that firms can choose which R\&D projects to pursue (Atkinson, 2007; Elschner et al., 2011; Tassey, 2007). Their effect is reflected in reduced marginal cost of R\&D investment (Castellacci \& Lie, 2015). Market neutrality of R\&D tax incentives can also be regarded as their weakness, given that in some situations it might be socially optimal for a government to support those industries and innovation activities that have a potential to produce large spillover effects (Baghana \& Mohnen, 2009). The government objective when using this policy instrument is to influence the overall level of industry R\&D activities, rather than to change its composition, which can be done via R\&D subsidies (Atkinson, 2007; Elschner et al., 2011; Tassey, 2007). This can be particularly effective in the case of SMEs, because raising a level of R\&D activities through R\&D tax credits can, at least partly, reduce financial constraints that are pertinent to small businesses (Baghana \& Mohnen, 2009; Elschner et al., 2011).

Unlike tax incentives, $R \& D$ subsidies are not market neutral as $R \& D$ tax credits, because they usually target particular sectors, technologies or stages of the R\&D cycle (Engel et al., 2019; Tassey, 2007). Regarding the latter, R\&D subsidies can predominantly be beneficial in early stages of research that entail higher costs (Atkinson, 2007; Tassey, 2007). While tax incentives reduce the marginal cost of R\&D, a direct government support via $R \& D$ subsidies results in an increase of the marginal rate of return of R\&D (Castellacci $\&$ Lie, 2015). Unlike tax incentives that target all R\&D performers, a direct government support is subject to the approval of a subsidy application that a firm submits to an awarding public agency. Therefore, the preparation of a project proposal is not costless, as it requires the use of time of qualified personnel (Busom et al., 2014). In summing up, while tax incentives are market neutral such that all R\&D performers would qualify, only firms that engage in highly innovative $\mathrm{R} \& \mathrm{D}$, that are of high risk and/or have a potential of large spillover effects would qualify for a subsidy (Busom et al., 2014; 2017).

The study offers several contributions to the policy evaluation literature. First, empirical evidence on the instrument policy mix in the context of output additionality is very limited. Most empirical evaluations, whether on the individual effects of R\&D subsidies or tax credits or their joint effectiveness, investigate input additionality, i.e. the policy effects on innovation inputs, such as R\&D expenditures (Castellacci \& Lie, 2015; Dimos \& Pugh, 2016). An important issue in innovation analysis is how firms transform innovation inputs into marketable products and improvements in productivity. Consequently, evaluation of public support should go beyond the examination of its effectiveness on innovation inputs, and provide evidence whether public support facilitates firms in transforming R\&D (and non R\&D) innovation investments into new products (and thus increased profitability) and/ or new processes (and thus increased productivity). Therefore, research in this study contributes to very limited empirical evidence on the impact of instrument policy mix-individual effects of R\&D subsidies or tax credits or their joint effectiveness-in the context of output additionality. Increasing complexity of policy instruments and objectives brings forward the need for policy evaluation that will support the design of optimal, evidencebased policies (Meissner \& Kergroach, 2021). Existing policy mixes have emerged from a random policy layering rather than from a planned policy design (Howlett et al., 2015; Schmidt \& Sewerin, 2019). Therefore, impact studies of policy mixes contribute to the evidence-based policy and provide empirical evidence whether a theorised complementarity within policy mixes occur in practice.

Second, most previous studies use binary indicators for policy treatments (Dimos \& Pugh, 2016). Our study reports empirical findings for both cases-when the policy variables are continuous and when they are binary. With this practice, we want to check if our 
findings change depending on the operationalisation of policy variables. Third, by estimating dynamic probit models, we are able to account for a number of econometric issues identified in the innovation evaluation literature, but mostly not accounted for because of lack of data. Namely, the adopted empirical strategy takes into account the persistence of innovation (by including a lagged dependent variable) and unobserved heterogeneity. These issues cannot be addressed in cross-sectional studies, which dominates this stream of research. Finally, we analyse SMEs and large firms separately. Given well-known differences in innovation activities in these firms, we explore whether the instrument policy mix could have a differentiated effect in SMEs compared to large firms.

Regarding empirical results, we find no evidence of the joint impact of R\&D subsidies and $R \& D$ tax credits on innovation activities related to new products and process development in Spanish manufacturing firms, but find strong evidence with respect to the highest impact of the past innovation activities on the present engagement in product and process innovations. Furthermore, we find a strong evidence of spurious state dependence given the positive impact of initial engagement in product and process innovations on their current adoption and a stronger past dependence for product than process innovations. Similar results occur for SMEs and large firms separately, with the only difference related to R\&D subsidies: highly significant impact for SMEs and insignificant for large firms. Our study is among the first to estimate the impact of both propensity and intensity of receiving direct and indirect support, demonstrating that support to firms with a potential for innovation might have strong policy effects, but support to firms that are already innovating might not produce optimal results. Our findings provide valuable insights to policy makers on how to design an effective supply-side innovation policy in Spain.

This study is organised as follows. Section 2 discusses the supply-side innovation policy in the context of Spain. Section 3 reviews background literature on the effectiveness of tax incentives relative to R\&D subsidies and grants, the concept of the instrument policy mix, previous empirical evidence on this topic and types and sources of persistence of innovation. Section 4 gives an overview of the empirical strategy, data and sample used in the study, and the model specification. Section 5 presents our results while Sect. 6 discusses key policy implications and suggestions for further research.

\section{Context of the study}

To stimulate business R\&D activities, both R\&D subsidy schemes and R\&D tax incentives have been simultaneously available to firms in Spain since 1980s (Busom et al., 2017) and were further developed in 2004 and 2014. Tax relief is provided through a hybrid (volume-based and incremental) R\&D tax credits and social security contribution exemptions for qualified full-time R\&D personnel (40\% tax reduction to employers' social security contributions). Compared to other OECD or EU countries, R\&D tax incentives in Spain in 2018 were one of the most generous, although generosity has declined over the 2008-2018 period (due to the global financial crisis). From 2002 to 2016, the government support through tax incentives remained more or less stable-oscillated around $0.03 \%$ of GDP-reaching the magnitude of EUR 356 million (in 2010 prices) in 2016 and the share of tax incentives in total government funding amounted to 36 percent. In 2018, a marginal tax subsidy rate for profitable SMEs as well as for profitable large enterprises is estimated at 0.33 . The rate for SMEs is slightly over OECD median of 0.20 and substantially higher for large enterprises than OECD median of 0.13 (OECD, 2019). 
Direct government funding for business $R \& D$ and innovation activities is channelled through an elaborated system of public agencies, such as the Spanish Research Agency and the Centre for Industrial Technological Development. From 2009 to 2014, the total government financial support to business R\&D and innovation activities oscillated between 64 and 51 percent (a fall mainly due to the global financial crisis). In 2015, the volume of government funding amounted to EUR 5959 million. A comparison between government direct funding vs. tax credit indicates that the main instrument for supporting business $\mathrm{R} \& \mathrm{D}$ and innovation activities in Spain is a direct government funding.

\section{Literature review}

\subsection{On the relative effectiveness of using tax incentives compared to subsidies and grants}

Government support for R\&D can be direct or indirect. Grants, subsidies and loans are instruments of so-called direct government support, while tax incentives, especially tax credits are instruments of so-called indirect government support. These are also the most common proxies for government support in empirical evaluations of the causal impact of policy intervention. ${ }^{1}$ The balance of direct and tax support for R\&D varies from country to country and can changed over time since both measures stimulates different types of R\&D (Appelt et al., 2016). Governments steer direct support in the form of grants, subsidies and loans, towards R\&D projects that are considered as most likely having the largest gap between social and private rates of return (Klette et al., 2000; Wallsten, 2000). On the other hand, tax incentives are typically directed to all firms (Busom et al., 2014, 2017). Besides, tax credit does not alter a firm's choice of R\&D projects and the support is not affected by the selection bias often linked to the R\&D projects funded by public agencies (David et al., 2000). Tax incentives do not usually condition the provision of support other than implied by a pre-defined tax rule (Appelt et al., 2016) ${ }^{2}$ This implies that potentially many categories of firms can be reached since tax credit is easily to claim for a recipient as it can be deducted from all tax and social security liabilities, providing that firms have enough tax and social security liabilities to benefit from the full value of the tax credit and that rules are not overly restrictive.

Both measures have limitations. A disadvantage of grants and subsidies is that are highly dependent on discretionary decision of government bodies and/or public agencies, their effectiveness on the information available to the policy makers that manage R\&D programmes, and on the strategic priorities set by them. In addition, firms might successfully lobby for subsidies that are in their interest, possibly diverting subsidies in ways that are not conducive to innovation (Mazzucato, 2018a).

A disadvantage of tax credit support is that firms receiving funding for $R \& D$ projects ex-post, must be able to finance the projects in advance (Busom et al., 2014) which can be especially problematic for innovative young SMEs as those firms often face financial constraints, both internal and external (Hajivassiliou \& Savignac, 2011). The use of tax credits for $\mathrm{R} \& \mathrm{D}$ projects having the largest gap between social and private rates of return is not

\footnotetext{
1 Governments can influence R\&D activities also by public investments, or by funding private sector research through loans and contracts.

2 Although some countries require a pre-approval or accreditation (Appelt et al., 2016).
} 
the most appropriate policy instrument, as such projects are financially very demanding, time-consuming and would therefore require large tax changes. Further, in case of frequent changes of tax incentives, firms' planning of R\&D investment becomes difficult, which, in turn, can marginalize the effect of tax incentives.

To conclude, the use of tax incentive compared to subsidies and grants is after all the choice of individual country and its policy objectives. However, there appears a broad consensus that direct support (grants and subsidies), is more suitable for supporting high risky research and for supporting projects that generate public goods. In contrast, tax incentives are more suitable for R\&D activities which outcomes can be brought on the market within a reasonable time frame (Appelt et al., 2016).

\subsection{Instrument policy mix}

Contemporary innovation policy is characterised by a combination of policy instruments designed to promote firms' innovation activities, which is termed the instrument policy mix. ${ }^{3}$ A proliferation of various policy instruments is a result of policy efforts to mitigate two groups of failures in relation to innovation. The first is a well-known neoclassical market failure argument, while the second is associated with systemic failures arising from the interaction of organizations and institutions within systems of innovation. Consequently, the interactions and interdependence between different policy instruments calls for a type of policy evaluation that will take into account a joint impact of various policy instruments on firm's innovation performance (OECD, 2010; Uyarra, 2010; Flanagan et al., 2011; Magro \& Wilson, 2013; Cunningham, Gök, et al., 2016; Cunningham, Edler, et al., 2016; Flanagan \& Uyarra, 2016). The reason for this is twofold: first, the main feature of innovation policy is its complexity, and second, because of the relative failure of European R\&D and innovation policy to close the productivity gap between Europe, on the one side, and the USA and Japan on the other (Cunningham, Edler, et al., 2016; Cunningham, Gök, et al., 2016; Radicic \& Pugh, 2017). However, the evidence on the effectiveness of policy mix is very scarce, because of the difficulties in conducting such evaluation (most prominently due to the lack of data) and because it is argued that policy makers show lack of interest for this kind of evaluation (Cunningham, Edler, et al., 2016; Cunningham, Gök, et al., 2016).

Theoretically, the interaction in the policy mix could result in: a) complementary or synergistic effects; b) trade-offs, such that one instrument reduces the effectiveness of the other(s); and c) no interactions between instruments (Cunningham, Gök, et al., 2016; Cunningham, Edler, et al., 2016; Magro \& Wilson, 2013; Martin, 2016; OECD, 2010). The innovation effects of policy instrument mixes occur at the firm level. If the complementary effects are absent, managers in innovative firms might not necessary be aware of the lack of the policy mix effectiveness. That is, if their firm is eligible, managers would apply for different government support programmes, assuming that individual and joint innovation effects of the programmes will be positive. In contrast, government agencies conduct impact evaluation whose purpose is to investigate whether a particular government policy or instrument (or a mix of them) produces expected effects. In case of the instrument mix, it is expected that the joint effect of two (or more) policy instruments is complementary. However, suboptimal outcomes of policy mixes are very common in cases of policy

\footnotetext{
${ }^{3}$ Innovation policy mix is a broader term and encompasses not only the instrument policy mix, but also a multi-governance policy mix (at different governance levels) and a policy mix across space and time (Flanagan et al., 2011). The focus of our study is on the instrument policy mix.
} 
layering, i.e. adding new policy tools and objectives to old ones (Howlett et al., 2015). If the objective of policy makers is to achieve an optimal policy mix, rather than the optimal outcome of individual instruments and objectives, then policy mechanisms should be jointly implemented, rather than individually (del Río, 2014). Moreover, policy coordination is needed so duplication and overlap of efforts can be either minimized or completely avoided. However, the lack of coordination is quite common between isolated government departments that design and implement related policies (Magro et al., 2014). Therefore, all three outcomes of the policy mix (complementarity, substitution or no interaction) could be potentially reported when conducting a quantitative evaluation.

\subsection{Previous empirical evidence}

Most of the empirical policy evaluations concentrate on input additionality (Castellacci \& Lie, 2015; Dimos \& Pugh, 2016), testing the crowding-in and crowding-out hypothesis, i.e. on the nature of the effect of government funding of $R \& D$ on private firms own $R \& D$ expenditure. ${ }^{4}$ Two other types of additionality- output and behavioural, are subject of a smaller number of empirical studies. Output additionality, in particular, is a diverse topic, as innovation outputs and firm performance are proxied by a wide array of measures: patents, various types of innovation (product, process, organizational and marketing), innovative sales, productivity, profitability, employment, etc.

Concerning policy instruments, researchers have mostly studied the causal effect of subsidies, while studies examining the impact of tax credits are more limited, in spite the use of tax credits as policy instrument has significantly increased after 2000. ${ }^{5}$ Dimos and Pugh (2016), in their meta-analysis of R\&D subsidies regarding input and output additionality, conclude that most studies report positive, but small policy effects. Castellacci and Lie (2015) conduct a meta-analysis of the effectiveness of R\&D tax credits in supporting firms' innovation activities, but only in the context of input additionality, as there are very few studies investigating output additionality.

Empirical evidence on the joint impact of R\&D subsidies and R\&D tax credits is also rather limited (Testa et al., 2019) and most of the studies focus on input additionality (for a review see Dumont, 2017). Investigating their joint impact in our study contributes to two important concepts in innovation evaluation studies. First, considering their individual and joint effectiveness, we avoid a hidden treatment bias (Dumont, 2017; Guerzoni \& Raiteri, 2015). The bias refers to potential overestimation of the policy effect when a single policy instrument (either R\&D subsidies or R\&D tax credits are analysed separately). Second, by estimating a joint effect, our study adds to the empirical evidence in relation to the innovation policy mix.

Among few studies investigating the instrument policy mix, the following two focus on input additionality. Dumont (2017) analysed the policy mix in Belgium and reported robust evidence of the lack of additional effects. The author argues that this finding could be explained by the lack of policy coordination. Marino et al. (2016), in the context of French firms, found a substation effect when firms received larger R\&D subsidies as well as R\&D tax credits. Berubé and Mohnen (2009) is among very few studies that investigate the instrument policy mix with respect to output additionality. They report that Canadian

\footnotetext{
4 This section is partly based on Petrin (2018).

5 Today tax incentives present the major source of allocation of public funds to SMEs in OECD countries (Cunningham et al., 2016a, 2016b; OECD, 2014).
} 
firms are more likely to introduce product innovation and have higher innovative sales if they claim tax credits and also receive subsidies. However, the authors apply a propensity score matching, which means that unobserved heterogeneity could not be controlled for. Moreover, given the use of a cross-section data, it was not possible to control for the persistence of innovation. Both of these are accounted for in our study.

Furthermore, we looked at studies that separately investigated SMEs and large firms. We could not find any that report the findings in the context of the instrument policy mix, so we briefly review studies examining individual policy instruments. Most of the reviewed studies evaluating the effect of direct public support on the innovation performance of SME have found positive output additionality effect. Foreman-Peck (2013) has estimated the UK innovation policy impact on a large sample of both service and manufacturing SMEs. Propensity score matching indicates that SMEs receiving UK state support for innovation were more likely to introduce product and process innovations than unsupported comparable enterprises. Bronzini and Piselli (2016), in case of the Northern Italy innovation programme during early 2000s, found a significant impact on the number of patent applications, particularly in the case of smaller firms. It also increased their likelihood of applying for a patent. Czarnitzki and Delanote (2015) evaluated the current focus of EU policy on independent young SMEs in high tech sectors and found that current policy focus is effective. Positive effect of R\&D subsidies was also found by Radicic et al. (2016) who performed analysis of treatment effect on a wide range of innovation outputs in European SMEs. They found positive effects of innovation support programmes, typically increasing the probability of innovation and its commercial success by around $15 \%$. Radicic and Pugh (2017) report positive impact of national and international programmes on innovative behaviour of European SMEs-positive treatment effect was found for the propensity for patent application, but not on innovative sales. Guo et al. (2016) in the case of Chinese government Innovation Fund for SME support found that it generated higher number of patents and sales from new products and exports.

Dechezleprêtre et al. (2016), analysing the impact of tax change on both patenting and R\&D expenditure on the UK SMEs, found a significant impact of tax change on both R\&D expenditure and patenting: $R \& D$ approximately doubled in the treated group from a subpopulation of SMEs and patenting rose about 60 per cent. Results show also that the R\&D generated by tax policy crates spillovers on innovation of technologically related firms. Regarding the instrument policy mix, we could not find any empirical studies focusing specifically on SMEs.

Pless (2021) investigates the policy mix of R\&D subsidies and R\&D tax credits separately for small and large firms in the United Kingdom. She reports a complementary effect in small firms, but a substitution effect in larger firms. However, these results cannot be compared to ours, as Pless (2021) examines input additionality (impact of public support on $R \& D$ expenditure) and output additionality with respect to productivity. In addition, the definitions of small and large firms are different; while small firms in Pless (2021) are defined as having between 20 and 80 employees, we adopt the definition of the European Commission (2008), according to which SMEs have less than 250 employees.

In summary, the evidence presented on output additionality at the firm level suggests that direct government support such as grants, subsidies or tax credit may positively impact innovation outcomes firms with greater impact on firm innovation output generally found for SMEs than for large firms. This finding can be explained by financial constraints small firms are facing which prohibits them to undertake more risky investment like innovations. A large body of empirical evidence suggests that small firms primarily finance new investments with internal funds, implying a relatively high cost of external financing of R\&D 
investment compared to internal funding. The evidence also supports the important role of venture capital for bridging financial constraints due to a limited access to debt financing, and that government funds are playing a significant role in facilitating the growth of small firms through preferential R\&D tax treatments, as well as in the form of direct support such as grants and subsidies (Revest \& Sapio, 2012). A direct financial support is seen as more effective for SMEs, since it is usually provided up front compared to R\&D tax credits of which the benefits can be obtained after the completion of the innovation project. Alternatively, the large effects for small firms can be explained if sunk cost of R\&D are high and capital has relatively low salvage value and thus also limited resale value (Dosi, 1990). In such cases the provision of $R \& D$ subsidies might help small companies to overcome this threshold and decide for risky innovation investments (González and Pazó, 2008).

\section{Methodology}

\subsection{Persistence of innovation}

Although the focus of the study is on the effectiveness of innovation policy mix, our empirical strategy incorporates an important dimension of innovation persistence that is often overlooked in empirical studies. To take into account the persistence of innovation, our empirical strategy encompasses dynamic models of product and process innovations. Concerning product innovation, several theoretical arguments support its persistence. The first relates to sunk costs (Sutton, 1991) associated with firms' initial R\&D investments, such as the establishment of R\&D department and hiring R\&D staff (Antonelli et al., 2012; Clausen et al., 2011; Ganter \& Hecker, 2013; Haned et al., 2014; Peters, 2009; Triguero \& Córcoles, 2013). The second is the 'success breeds success' argument, whereby a successful introduction of new product in one period enables firms to gain market power, which, in turn, increases the likelihood of future successful innovation (Flaig and Stadler, 1998). The third potential explanation for the persistence of product innovation arises from the appropriation theory. Following Tavassoli and Karisson (2015), new products are more likely to be protected using formal mechanisms of Intellectual Property Rights (IPRs), than other types of innovation. This is due to a tacit nature of knowledge embedded in other types of innovation, which makes them harder to protect and easier to imitate.

Besides product innovation, another type of innovation that is characterized by a persistent occurrence is process innovation. Firms engage in this type of innovation to reduce unit costs and enhance productivity through changes in techniques, equipment and software (Hwang et al., 2015). The literature advances several arguments as to why firms might persistently engage in process innovation. The first argument is common with product innovation and associated with R\&D sunk costs, insofar as new products require changes in production methods. In addition, Clausen et al. (2011) note that the persistence of process innovation is conditional on industry characteristics, i.e. it often occurs in mature industries, in which the importance of process innovation is reflected in a firm's efforts to implement more efficient production methods, rather than new products.

In general, persistence of any process can be divided into two categories. The first is true state dependence or path dependence, which, in the context of innovation activities, means that firms that introduced innovation in the previous period (period $t-1$ ) are more likely to introduce innovation in the current period $t$ (Antonelli et al., 2013; Ayllon and Radicic, 2019). The second type of persistence is termed spurious or past dependence, 
whereby firm characteristics, including initial conditions, affect the probability of observed persistence. Past dependence can be associated with firms' internal resources and their impact on innovation as elaborated in the resource-based view and the dynamic capacities approach (Antonelli et al., 2013).

\subsection{Empirical strategy}

In the literature on innovation policy evaluation, there is a there is a prevalence of matching estimators in the context of a cross-sectional data analysis (Czarnitzki \& Lopes-Bento, 2013; Czarnitzki et al., 2011). The main advantage of matching estimators, from the perspective of econometric strategy, is that they do not require an exclusion restriction(s), as finding them is a very challenging task in innovation evaluation studies (Czarnitzki \& Lopes-Bento, 2013; Czarnitzki et al., 2011; Henningsen et al., 2015). That is the reason why the instrumental variable (IV) approach (and selection models) is seldom applied in this stream of research (Ichimura \& Taber, 2001). With respect to a panel data analysis, two recommended estimators are a difference-in-differences and a regression discontinuity method (Imbens \& Wooldridge, 2009). We are unable to use these estimators because we do not know when firms received $R \& D$ subsidies, thus we do not know when the treatment started (i.e. when the change of subsidy status occurred, which is necessary for a difference-in-differences estimator) and policy instruments under investigation do not have a threshold value (which is necessary for a regression discontinuity method (Imbens \& Wooldridge, 2009). Consequently, evaluation studies analysing a longitudinal panel data often use other panel estimators. Henningsen et al. (2015) use a fixed effects (FE) panel estimator to estimate input additionality in Norwegian firms. The authors comment why they cannot use the regression discontinuity estimator. Similar to our case, they do not have a threshold value (which is a single variable that the granting agency constructs to sums up the quality of the proposal). Dumont (2017) is another example of the study in which a panel data analysis is used for impact evaluation. The author explores the impact of the instrument policy mix on input additionality in Belgium. Empirical strategy adopted in the study includes a fixed effects (FE) estimator and a generalized methods of moments (GMM) estimator. Given that our dependent variables are not continuous, we are unable to use these estimators. Huergo et al. (2016) is the study that adopts the same empirical strategy as in our study, whereby the authors estimate a random effects dynamic probit model to explore input additionality in Spanish SMEs and large firms.

Given the above discussion, we draw on the innovation persistence literature (Peters, 2009; Tavassoli \& Karlsson, 2015) and model the innovation knowledge function using a dynamic probit specification. A dynamic specification is used because of persistence, which is termed state dependence, i.e. firms that are innovating in the any given period are more likely to innovate in the next period. We assume that firms can be characterized by a latent product or process innovation propensity $\left(y_{i t}^{*}\right)$ such that:

$$
y_{i t}^{*}=\alpha y_{i t-1}+\beta_{1} \text { Subsidies }_{t-1}+\beta_{2} \operatorname{Tax}_{t}+\beta_{3} \text { Subsidies }_{t-1} * \operatorname{Tax}_{t}+\gamma Z_{i t-1}+c_{i}+u_{i t}
$$

The latent outcome variable $y_{i t}^{*}$ captures the probability of introducing product or process innovation, while $y_{i t}$ is the observed binary variable. $y_{i t-1}$ represents product or process innovation in the previous period, $Z_{i t-1}$ is a set of time-varying lagged explanatory variables 
that are considered exogenous; Subsidies $_{t-1}$ and Tax $_{t}$ are the variables of interest (R\&D subsidies and R\&D tax credits respectively and their interaction term Subsidies $_{t-1}{ }^{*}$ Tax $_{t}$ ); $c_{i}$ captures unobserved firm heterogeneity ${ }^{6}$; and $u_{i t}$ is the idiosyncratic error term (Grotti $\&$ Cutuli, 2018). The coefficient $\alpha$ captures the degree of true or genuine state dependence of the dependent variable (either product or process innovation). That is, $\alpha$ measures the extent to which engaging in product or process innovation in period $t-1$ affects the likelihood of current product or process innovation in period $t$. Furthermore, we assume $y_{i t}=I\left(y_{i t}^{*}>0\right)$, that is, binary indicator functions that are equal to 1 if the latent propensity is positive and 0 otherwise. The subscripts $i$ and $t$ refer to cross-sectional units (firms in our case $i=1, \ldots$,$) and time periods (t=2001, \ldots, 2016)$ respectively. Our main interest lies in the coefficient on the interaction term $\beta_{3}$. In the literature which investigates complementarity between variables or public policies, this is known as the interaction approach (for a detailed discussion see Guisado-González et al., 2018). ${ }^{7}$ The sign and the significance of the coefficient on the interaction term ( $\beta_{3}$ in our models) is used to evaluate whether two policy instruments are complementary. Specifically, if the coefficient $\beta_{3}$ is positive and statistically significant, that can be interpreted as the evidence of complementarity. In contrast, if the coefficient is negative and statistically significant, two policy instruments are substitutes. Finally, a statistically insignificant coefficient suggests that there is no relation between policy instruments (Guisado-González et al., 2018).

To estimate a dynamic probit model specified in Eq. 1, we need to make the assumptions about the initial status of product (or process) innovation $y_{i 1}$, which is the status of a firm at the beginning of the sample period, and its correlation with the unobserved firm heterogeneity term $c_{i}$. If we assume the initial innovation status to be exogenous, the standard random effects probit estimator can be used for model estimation. However, the innovation status of a firm, $y_{i t}$ is not observed from its beginning. Therefore, treating it as exogenous variable in the estimation of a random effects probit model would results in biased parameter estimates because the lagged product (or process) innovation would be correlated with the unobserved firm heterogeneity term $c_{i}$ (Antonelli et al., 2012). This is known as the initial condition problem. As mentioned above, the coefficient $\alpha$ in Eq. 1 shows true state dependence, which is defined as a causal effect of previous engagement in product and process innovations on their propensity in the following period. However, besides true state dependence, another type of state dependence can occur if unobserved effects are correlated over time. This is known as a spurious state dependence. If initial conditions are treated as exogenous, then spurious dependence could be misinterpreted as a true dependence (Le Bas \& Scellato, 2014). That is why initial conditions need to be estimated and we follow the proposal by Wooldridge (2005) as shown in Eq. 2:

$$
c_{i}=\delta_{1} y_{i 1}+\delta_{2} \bar{X}_{i}+\delta_{3} X_{i 1}+\varepsilon_{i}
$$

\footnotetext{
${ }^{6}$ Unobserved firm heterogeneity refers to entrepreneurial attitude toward risk, managerial abilities and other firm-specific (idiosyncratic) characteristics that are not included in the model.

7 Complementarity in the R\&D literature is often thought as a complementarity test as in Cassiman and Veugelers (2006). The test is different to our approach, as in the former, potentially complementarity innovation activities ("make" and "buy") are measured as dummy variables. As we have both dummy and continuous variables of interest (R\&D subsidies and R\&D tax credits) we maintain the same empirical approach in both cases. In addition, to address the endogeneity issue, Casssiman and Veugelers (2006) use a two-step approach that requires exclusion restrictions. For these, the authors use two variables- Basic R\&D Reliance and appropriation conditions. However, for our variables of interest (R\&D subsidies and R\&D tax credits), the literature does not suggest any valid exclusion restrictions (as noted in Czarnitzki and LopesBento 2013; Czarnitzki et al., 2011; Henningsen et al., 2015).
} 
The unobserved specific effects $c_{i}$ are the function of the dependent variable in the initial period $\left(y_{i 1}\right)$, the initial values of all time-varying explanatory variables $\left(X_{i 1}\right)$ and the within-firm averages of the explanatory variables $\left(\bar{X}_{i}\right)$, where the averages are based on all periods $t=2001, \ldots, 2016 . \varepsilon_{i}$ is a firm-specific time-constant error term, normally distributed with mean 0 and variance $\sigma_{\varepsilon}^{2}$ (Grotti \& Cutuli, 2018). In other words, the distribution of the unobserved effects is conditional on the initial and average values of all explanatory variables and also on the introduction of product (or process) innovation in the first period in the sample. This approach produces a new unobserved heterogeneity term $\varepsilon_{i}$ that is uncorrelated with the initial value of the dependent variable $y_{i 1}$.

Thus, the dynamic model to be estimated is written as:

$$
y_{i t}^{*}=\alpha y_{i t-1}+\beta_{1} \text { Subsidies }_{t-1}+\beta_{2} \operatorname{Tax}_{t}+\beta_{3} \text { Subsidies }_{t-1} * \operatorname{Tax}_{t}+\gamma Z_{i t-1}+\delta_{1} y_{i 1}+\delta_{2} \bar{X}_{i}+\delta_{3} X_{i 1}+\varepsilon_{i}+u_{i t}
$$

The added components $\delta_{2} \bar{X}_{i}$, which are the average values across firms and years of panel data, address endogeneity arising from the correlation between explanatory variables and the error terms (Wen \& Maani, 2019; Wooldridge, 2010). When endogeneity is accounted for, the coefficients $\beta_{1}, \beta_{2}, \beta_{3}$ and $\gamma$ are unbiased fixed effects estimates. This is particularly relevant for the variables of interest. Since the seminal paper by David et al. (2000), it has been recognized that the evaluation of R\&D and innovation policy, in particular R\&D subsidies and tax credits, needs to take into account the endogeneity of public support, due to self-selection of firms and because public agencies might be following the "picking the winner" strategy (see also Czarnitzki \& Delanote, 2017; Henningsen et al., 2015).

\subsection{Data}

The dataset used in the study is the Spanish Business Strategies Survey (SBSS). This is a longitudinal survey conducted annually from 1990, covering all manufacturing sectors in Spain based on the NACE Rev. 1 classification. The dataset is gathered by the Public Enterprise Foundation and sponsored by the Spanish Ministry of Industry, Energy and Tourism. ${ }^{8}$ Although the survey gathers information on firms' performance and characteristics in general, many studies have used the SBSS data to analyse innovation-related research questions (e.g. Ayllón \& Radicic, 2019; Martínez-Ros \& Labeaga, 2009; Radicic \& Balavac, 2019; Santamaría et al., 2009). The sample is representative of Spanish manufacturing firms, and the sampling methodology is contingent on firm size. That is, firms with more than 10 and fewer than 200 employees are selected on the basis of a random stratified sample, while all firms with more than 200 employees are included in the survey (Triguero \& Córcoles, 2013).

Our sample is an unbalanced panel covering the period from 2001 to 2016. It excludes the period from 1990 to 2000, partly because more detailed information on innovation activities were first introduced in the 1998 survey (Santamaría et al., 2009). We limit our sample to $R \& D$ performers (i.e. firms with a positive $R \& D$ expenditure, see e.g. Marino et al., 2016; Romero- Jordán et al. 2014; Sterlacchini \& Venturini, 2019), given our focus

\footnotetext{
${ }^{8}$ For more information, see https://www.fundacionsepi.es/.
} 
on the impact of R\&D subsidies and R\&D tax credits on innovation performance. ${ }^{9}$ Regarding firm size categories, micro-sized firms are defined as those with fewer than 10 employees, small firms with more than 10 and fewer than 50 employees and medium-sized firms with more than 50 and fewer than 250 employees. This definition is consistent with the European Commission (2008) guideline.

Table 1 shows variable description and descriptive statistics. In the full sample, less than a half $(43.2 \%)$ of firms introduced product innovation, while slightly more than a half (53.8\%) engaged in process innovation. On average, firms received around EUR 400,000 of R\&D subsidies and around EUR 230,000 of R\&D tax credits. Market share on average is $13.7 \%$. Concerning cooperative activities, the largest number of firms cooperated with suppliers, HEIs and customers $(59.3 \%, 56.3 \%$ and $50.2 \%$ respectively), while a small number of firms $(7.7 \%)$ cooperated with competitors. ${ }^{10}$ The average firm size measured as a headcount is 486 employees, while the average firm age is 43 years. These descriptive statistics suggest that the data is skewed towards larger and older firms (which is similar to a sample of Belgian firms in Dumont, 2017). Given that we focus on R\&D performers, we would expect that larger firms are more pronounced in their R\&D investments than smaller firms. Older firms could be more represented in our sample, given that older firms are often larger firms as well. Moreover, the sampling strategy of the ESEE data is to collect information on all larger firms, while SMEs are selected through a random stratified sampling.

Most firms are exporters (84.7\%), while only a small number of firms searched for finance unsuccessfully (7.2\%). With respect to absorptive capacity, firms, on average, invested EUR $2.6 \mathrm{~m}$ in R\&D, while $65 \%$ of firms have their separate R\&D department or committee. Concerning human capital and innovation, almost a half of firms employed engineers and used advisors ( $45.8 \%$ and $45.2 \%$ respectively), while only $14.3 \%$ of firms employed staff with previous R\&D experience.

Looking at SMEs and large firms separately, while a similar number of both types of firms introduced product innovation on average (42\% of SMEs and $45 \%$ of large firms), a significantly larger number of large firms engaged in process innovation (49\% of SMEs and $60 \%$ of large firms). As expected, large firms are recipients of much larger amounts in terms of R\&D subsidies and R\&D tax credits. A smaller number of SMEs cooperate with any type of partner than large firms, although the largest difference is with respect to cooperation with HEIs ( $46 \%$ of SMEs versus $70 \%$ of large firms).

\subsection{Model specification}

The dependent variables in our models are Product innovation, a binary indicator equal to 1 if the firm introduced new or significantly improved goods or services in period $t$ (and zero otherwise) and Process innovation, a binary variable equal to 1 if the firm bought new machinery, and/or introduced new methods of organizing production and new software related to industrial processes in period $t$ (and zero otherwise). The variables of interests are two continuous variables, $R \& D$ subsidies $_{t-1}$ and $R \& D \_t_{t} x_{t}$. The former is lagged one period to account for the policy effect with a time lag (in natural

\footnotetext{
9 The reasons for focusing on R\&D performers are twofold. First, in line with previous studies (Aschhoff and Sofka 2009; Cassiman and Veugelers 2006; Grimpe and Kaiser 2010; Krzeminska and Eckert 2016; Lach 2002; Marino et al., 2016; Radicic and Balavac 2019; Schmiedeberg 2008), our aim to mitigate a potential selection bias due to firms self-selecting themselves into R\&D subsidies and R\&D tax credits. Second, only R\&D performing firms are eligible to apply for R\&D subsidies and R\&D tax credits.

10 All control variables are lagged one period to mitigate the problem of endogeneity.
} 


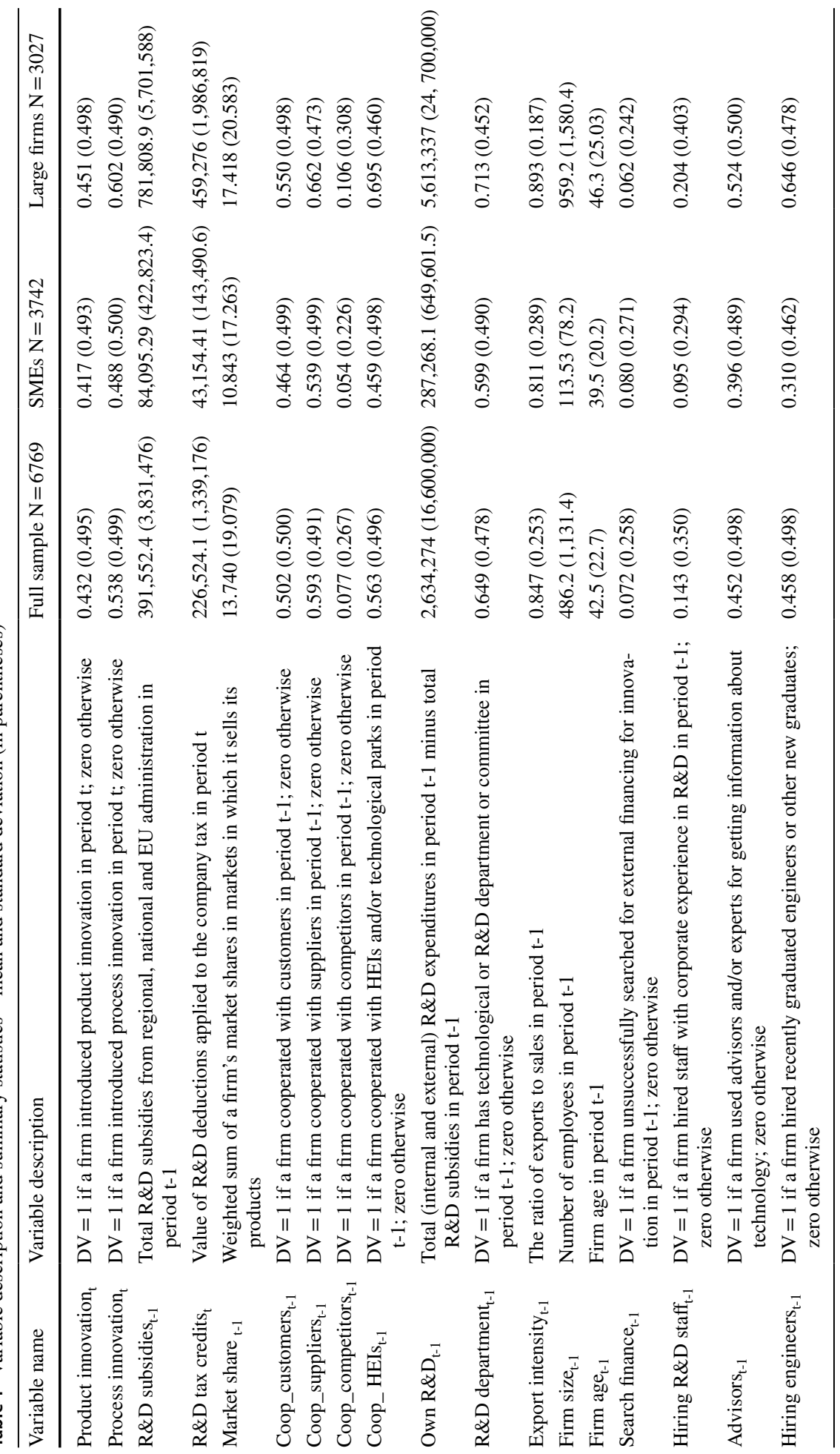


logarithm) (Czarnitzki \& Delanote, 2017; Dumont, 2017), while the latter is measured in period $t$, thus capturing an instantaneous effect (Castellacci \& Lie, 2015; RomeroJordán et al., 2014). Following David et al. (2000), the use and the impact of R\&D subsidies and R\&D tax credits is dictated by the conditions under which these instruments are provided to firms. Given that firms that are eligible for R\&D tax credits can choose innovation projects, they are more likely to use this type of incentive to engage in projects that are expected to generate higher private rates of returns and those profit would be generated in the short run. For this reason, we assume that the impact of R\&D tax credits on innovation activities will materialise instantaneously (in the same year). In contrast, projects with higher social rates of return and long-run projects are more likely to be supported by $R \& D$ subsidies. Therefore, we assume that the impact of $R \& D$ subsidies will not materialise instantaneously, but with a lag.

Control variables are lagged one period to take into account that the impact of firms' internal and external factors on innovation is not instantaneous, but rather occurs with a time lag (Busom et al., 2017; Radicic \& Pinto, 2019; Un \& Asakawa, 2015). They include a range of variables capturing firm and market characteristics. With respect to the latter, we control for a firm's market share, defined as the weighted sum of market shares in markets in which a firm sells its products (Marin, 2014). R\&D activities are particularly relevant determinants of product and process innovations and of absorptive capacity (Huang et al., 2010; Radicic \& Balavac, 2019). Concerning types of innovation, product innovation usually requires a certain degree of R\&D activities (Huang et al., 2010), while process innovation is more affected by non-R\&D activities (Polder et al., 2010; Rouvinen, 2002) and by collaboration with suppliers (Huang et al., 2010; Radicic \& Pinto, 2019). To operationalize absorptive capacity, we include more than one indicator, as suggested by previous studies (Hervas-Oliver et al., 2011, 2015). Accordingly, we model three variables as a proxy for absorptive capacity. The first is variable $O w n R \& D_{t-1}$, which measures total (internal and external) net R\&D investment (in natural logarithm) (Marino et al., 2016). The second is a binary variable equal to 1 if a firm has technological or R\&D department or committee, and zero otherwise (variable $R \& D$ department $_{t-1}$ ) (Hervas-Oliver et al., 2011). The third is Hiring $R \& D$ experienced staff $_{t-1}$ which is a binary variable equal to 1 if a firm hired R\&D experienced staff, and zero otherwise.

Firms' international activities are captured by the variable Export intensity ${ }_{t-1}$, as the ratio of exports to sale (Czarnitzki \& Hussinger, 2018; Marino et al., 2016; Torugsa \& Arundel, 2013). Variable Firm size t-1 $_{1}$ measures a number of employees (Hervas-Oliver et al., 2011; Torugsa \& Arundel, 2013; Un \& Asakawa, 2015). Variable Firm age t-1 accounts for firms' experience and learning (Hottenrott \& Lopes-Bento, 2016; Santamaria et al., 2009). To model coupled open innovation strategies, we include binary indicators for cooperation with four types of partners. The variable Cooperation with customers $_{t-1}$ is equal to 1 if a firm cooperation for innovation with customers in period $t-1$, and zero otherwise. The variable Cooperation with suppliers $s_{t-1}$ is equal to 1 if a firm cooperated with suppliers in period $t-1$, and zero otherwise. The variable Cooperation with competitors $s_{t-1}$ is equal to 1 if a firm cooperated with competitors in period $t-1$, and zero otherwise. Finally, the variable Cooperation with HEIs $s_{t-1}$ is equal to 1 if a firm cooperated with universities and/or technological canters in period $t-1$, and zero otherwise. Finally, other firm characteristics that might affect firms' innovation activities are captured by variables Search_finance ${ }_{t-1}$, Advisors $_{t-1}$ and Hiring_engineers t-1 $_{\text {(see Table } 1}$ for their descriptions). Industry heterogeneity is modelled by the inclusion of dummy variables for 20 sectors (see Table 1 for the list of sectors). 


\section{Empirical results}

First we interpret the models with product innovation as the dependent variable when R\&D subsidies and R\&D tax credits are measured as continuous variables (see Table 2). For each sample (full sample, SMEs and large firms), we first estimated models without the interaction term to evaluate the individual effects of R\&D subsidies and tax credits without taking into account their potential synergistic effect. The results are uniform across all three samples-while we find significant and positive effects of R\&D tax credits on the probability of product innovation, there is no such effect of R\&D subsidies. Similarly, with respect to the interaction term, our results suggest no interactive effect between R\&D subsidies and tax credits in any sample. ${ }^{11}$

Concerning control variables, we find heterogenous effects depending on firm size. Two common factors affect the propensity of product innovation across both SMEs and large firms: a large and highly statistically significant $(p<0.01)$ effect of the lagged product innovation (Product innovation $\left._{t-1}\right)$ and a large and highly significant $(p<0.01)$ effect of the initial condition with respect to product innovation. Accordingly, we report a positive autocorrelation between past and current product innovation; that is, the fact that a firm engaged in product innovation in the previous period is a powerful predictor of the current probability of product innovation. The fact that this result is robust even after controlling for unobserved heterogeneity suggests that there is true state dependence in the propensity to product innovation. Furthermore, once we control for the true and spurious state dependence, these effects dominate the impact of any other factor, whether those related to public support or to firm observed characteristics.

With respect to control variables that have a differing effect depending on firm size, for SMEs, we find a positive effect of cooperation with suppliers $(\beta=0.243, p<0.01)$, absorptive capacity proxied by the existence of $\mathrm{R} \& \mathrm{D}$ department $(\beta=0.169, p<0.05)$ and firm size (i.e. larger SMEs are more likely to introduce product innovation) $(\beta=0.003, p<0.05)$, while in large firms, hiring R\&D experienced staff has a positive and highly significant effect on the propensity to product innovation $(\beta=0.322, p<0.01)$. Finally, in terms of initial conditions other than those on product innovation, our results show a negative and highly significant $(p<0.01)$ effect of $\mathrm{R} \& \mathrm{D}$ subsidies in the initial period on contemporaneous product innovation in large firms. In other words, while we find no effect of receiving $\mathrm{R} \& \mathrm{D}$ subsidies in the previous period $t-1$ on the propensity of product innovation in period $t$, those large firms which received $\mathrm{R} \& \mathrm{D}$ support in the initial period are less likely to engage in product innovation in the current period.

Next we focus on the models with process innovation as a dependent variable (see Table 3). With respect to the individual effects of the variables of interest (models without interaction terms), receiving $R \& D$ subsidies has uniformly no effect on the propensity of process innovation, while $R \& D$ tax credits have a significant effect in the full sample $(p<0.05)$, but only marginally significant $(p<0.1)$ and very small effect in large firms. Similar to the models with product innovation, we find no evidence on the interactive effect of the joint R\&D subsidies and tax credits on the propensity of process innovation.

In terms of state dependence, the magnitude and significance $(p<0.01)$ of true state dependence is qualitatively the same as in the case of product innovation in all three

\footnotetext{
11 Correlation coefficients for the full sample as well as for SMEs and large firms separately are presented in Online Resource (Tables S1-S3). All correlation coefficients are low to moderate suggesting that multicollinearity is unlikely to occur.
} 


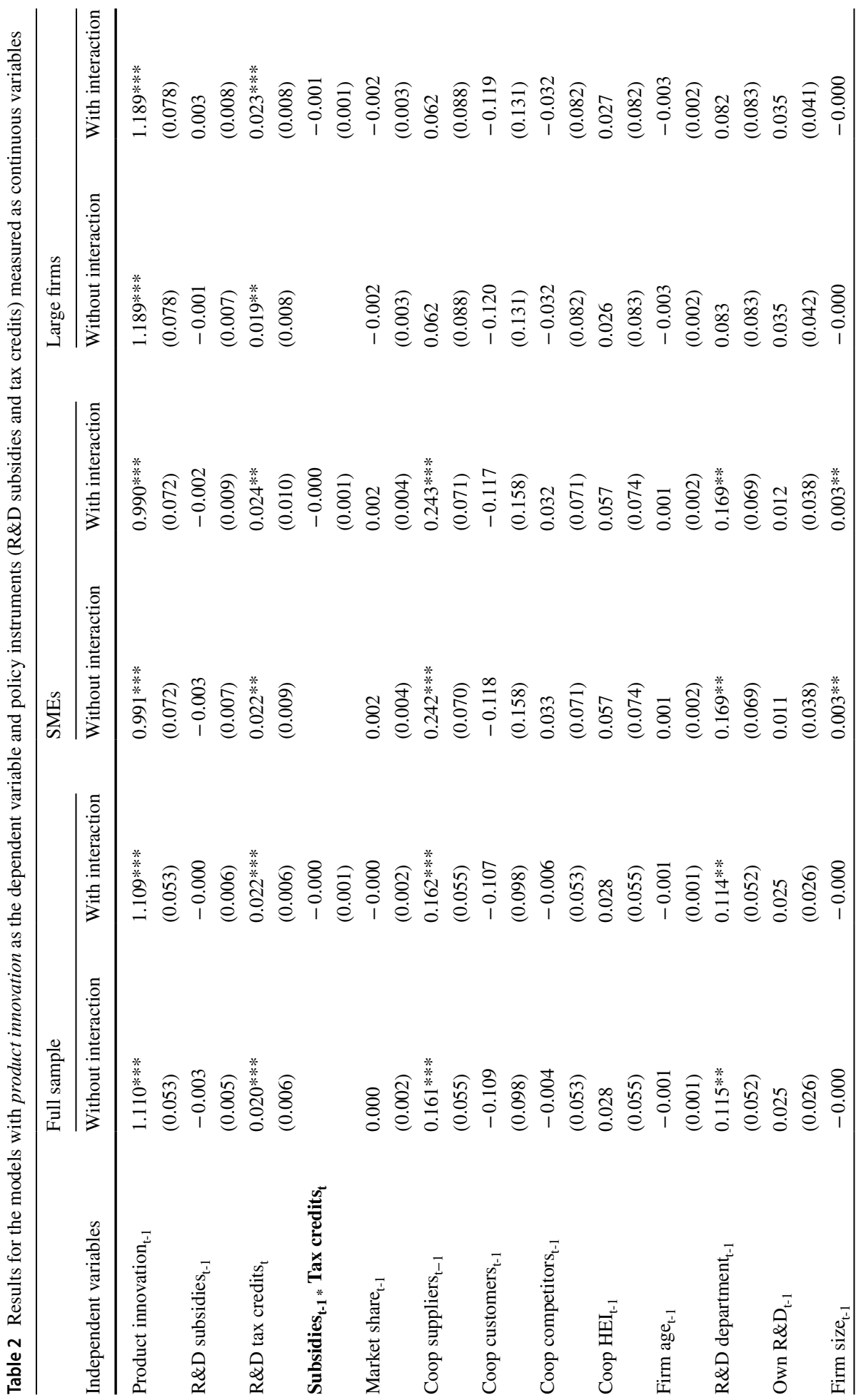




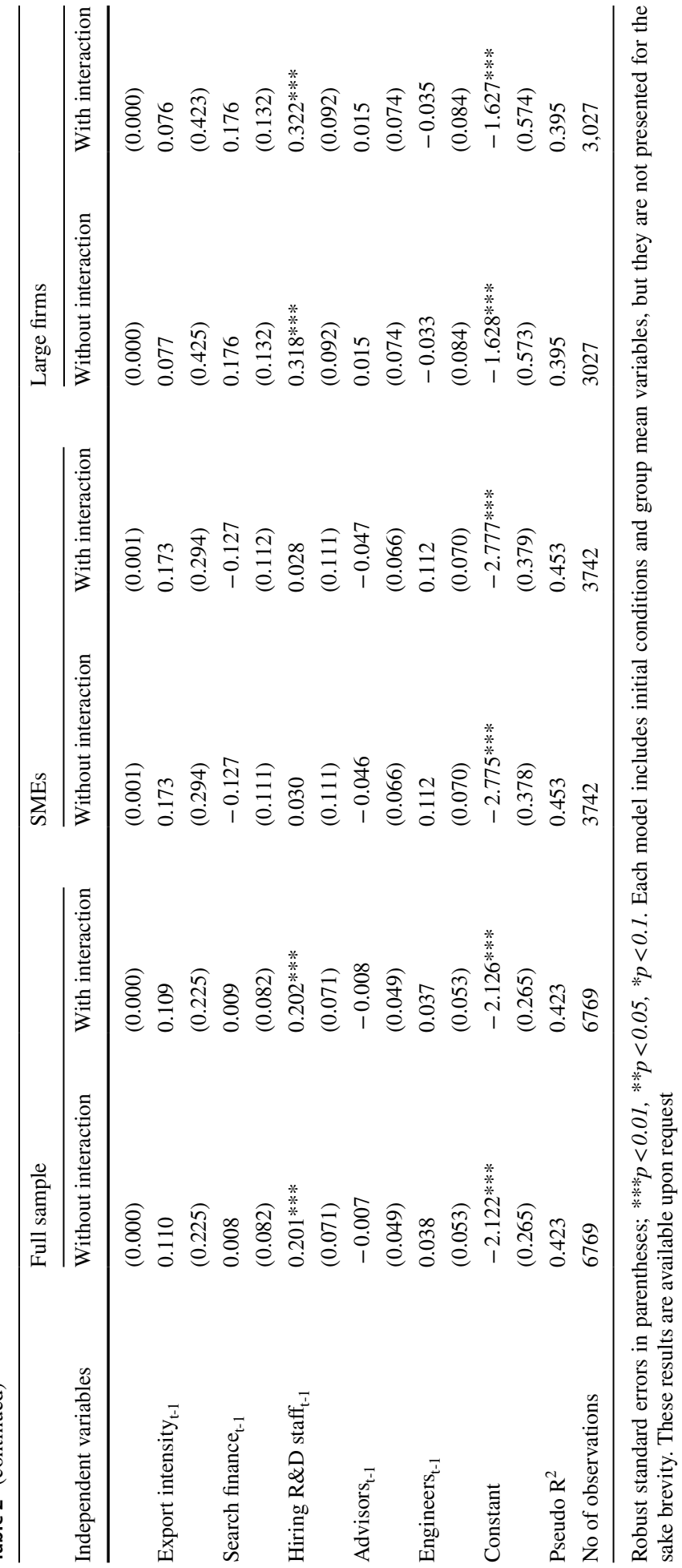




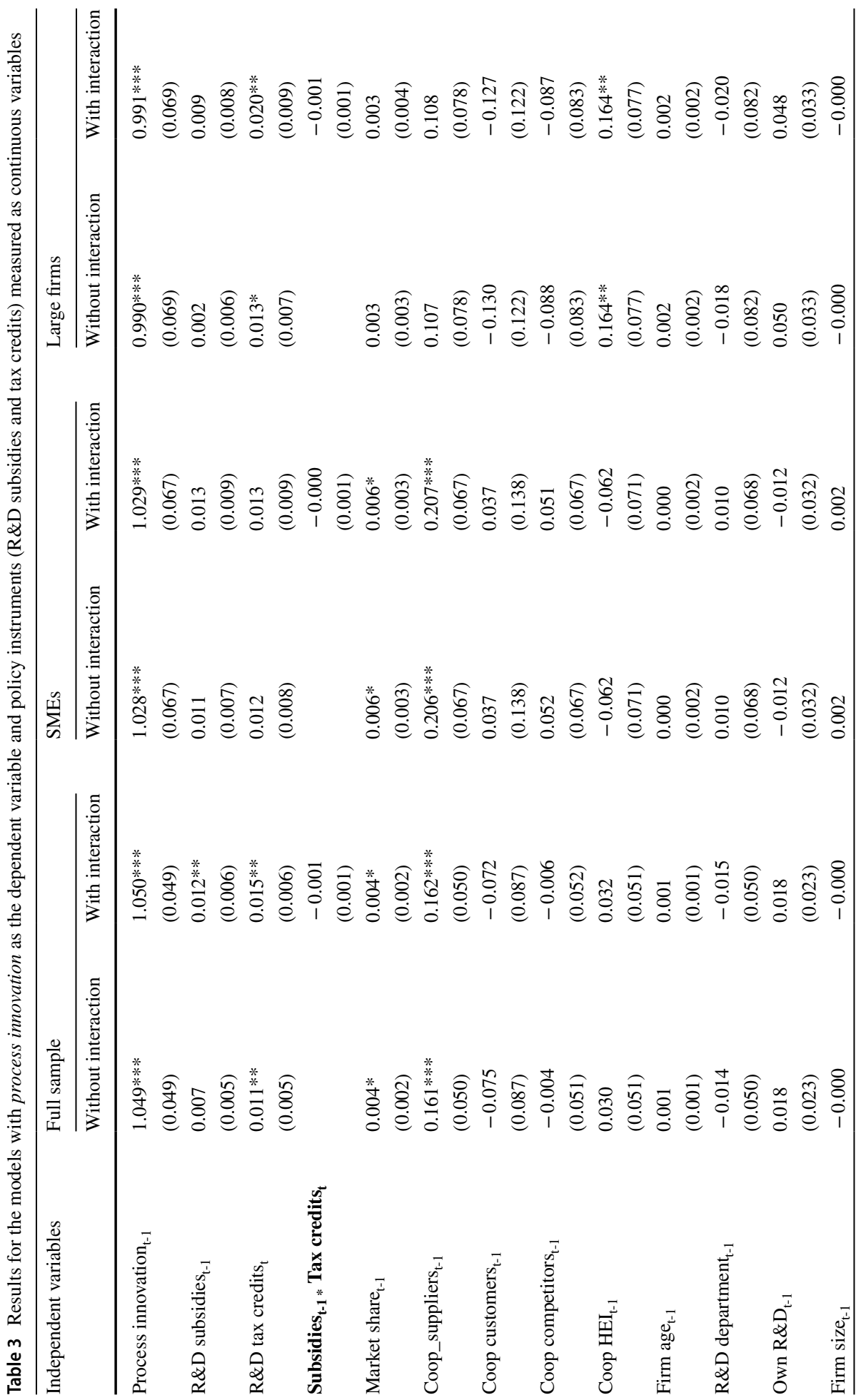




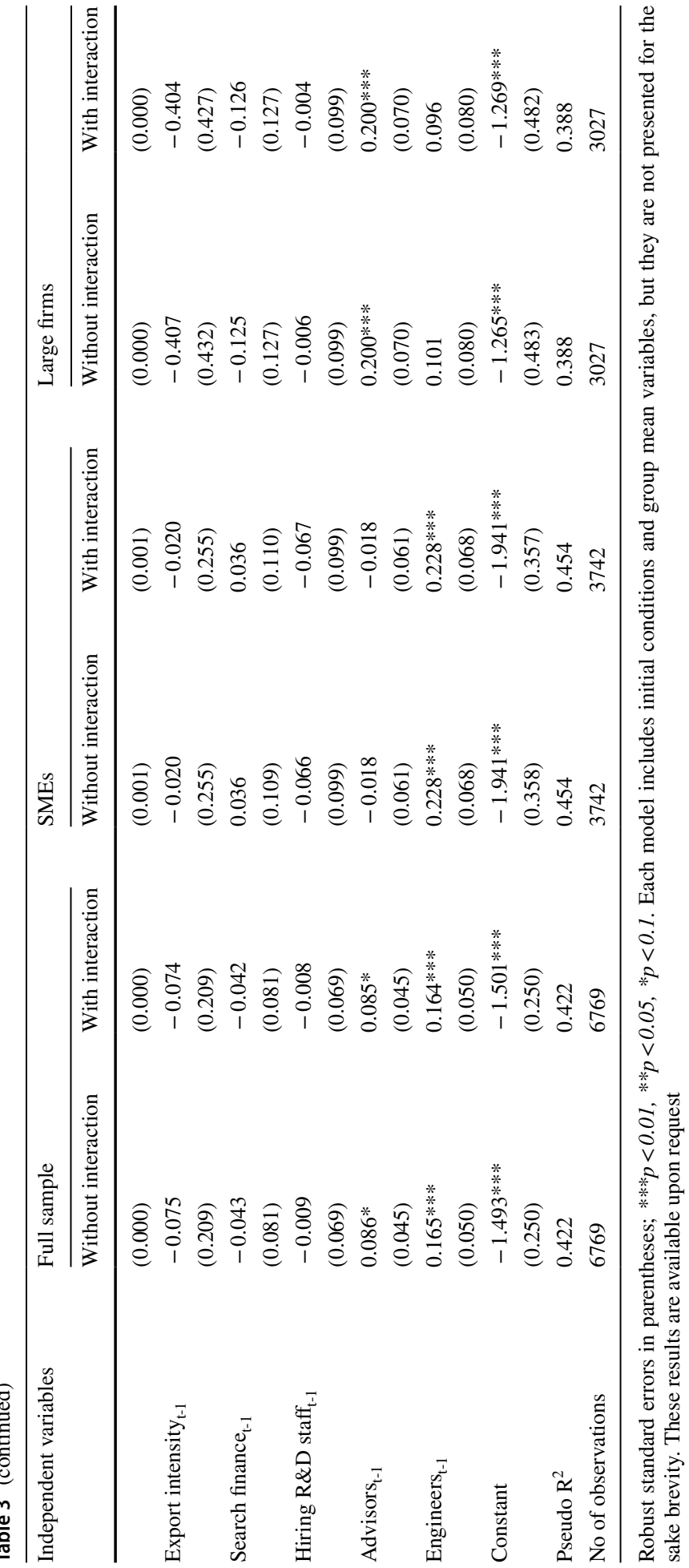


samples. Similarly, the coefficients on initial conditions for process innovation (Process innovation $\left._{t 0}\right)$, are large and highly significant in all three samples.

Focusing on control variables in SMEs, we find a marginally positive effect of market share $(\beta=0.006, p<0.10)$, a highly significant positive effect $(\beta=0.207, p<0.01)$ of cooperation with suppliers and hiring engineers $(\beta=0.228, p<0.01)$. In large firms, cooperation with customers has a positive and significant effect $(\beta=0.164, p<0.05)$ and using advisors $(\beta=0.200, p<0.01)$.

We conducted an additional analysis by replacing continuous variables of interest with binary variables (that is, whether firms received R\&D subsidies and applied for R\&D tax credits). This exercise has a two-fold task: a) to check whether the interaction between policy instruments varies when the propensity to public support (i.e. receiving R\&D subsidies and tax incentive) is modelled, instead of its intensity; b) whether the effectiveness of individual policy instruments changes, as these results might provide insightful policy recommendations in terms of propensity versus intensity of public support.

Table 4 shows the results for models with product innovation as the dependent variable. Three important findings are reported. First, similar to results in Table 2 (with continuous policy instruments), we find no individual effects of R\&D subsidies in any of the models. Second, the impact of R\&D tax credits on the probability of product innovation is positive and significant, which is in line with the results in Table 2, but the magnitude of estimated coefficients in Table 4 is much higher (a difference by one order of magnitude) from the corresponding coefficients in Table 2. Therefore, although qualitatively the results are the same whether R\&D tax credits are captured by a dummy variable or a continuous variable, the magnitude of the impact is much higher in the case of the former. Third, we find no evidence of the joint impact of R\&D subsidies and tax credits in the full sample as well as in the subsample of SMEs and large firms. Finally, with respect to persistence of innovation and the impact of control variables on the probability of product innovation, as expected, they are quantitatively the same in Table 4 as in Table 2.

Now we focus on our final models with process innovation as the dependent variable and the policy instruments modelled as binary variables (see Table 5). Regarding individual effects of $R \& D$ subsidies and $R \& D$ tax credits, the results are somewhat different compared to results in Table 3 (with binary policy instruments). Here we find a positive and significant $(\beta=0.121, p<0.05)$ effect of $\mathrm{R} \& \mathrm{D}$ subsidies on the propensity of process innovation in the full sample. This finding is also reported for SMEs (although only marginally significant, $\beta=0.142 ; p<0.1$ ), while not for large firms. Looking at the results for $R \& D$ tax credits, we note two differences between these results and those reported in Table 3. First, in the model for SMEs, the impact of R\&D tax credits is positive and significant $(\beta=0.161, p<0.05)$, while the corresponding coefficient in Table 3 is not statistically significant at any conventional level. Second, the impact of R\&D tax credits on process innovation in SMEs is now positive and significant $(\beta=0.161, p<0.05)$, unlike the corresponding coefficient in Table 3 , which is not statistically significant at any conventional level. Moreover, all the coefficients on R\&D tax credits are a one order of magnitude larger in Table 5 than in Table 3. These results might suggest that those studies that use binary measures of policy instruments might be overestimating the magnitude of policy effects. Finally, with respect to the instrument policy mix, we find no evidence of the consistence between $R \& D$ subsidies and $R \& D$ tax credits in models shown in Table 5, which is in line with findings from Table 3.

We conduct three types of robustness checks which produced a large number of additional results which can be found in Online Resource. The first robustness check includes the estimation of models without initial conditions (Tables S4-S7). The second robustness 


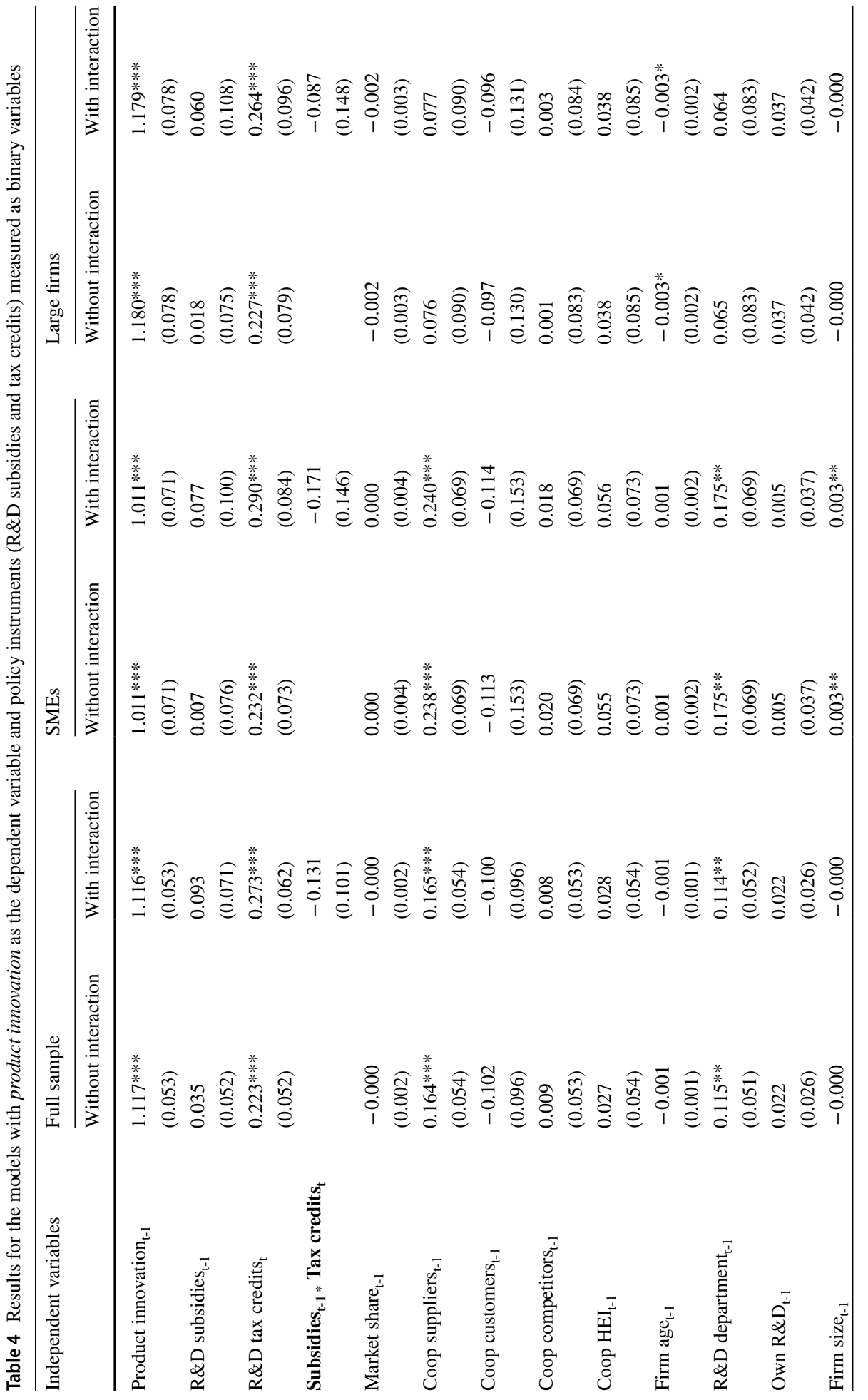




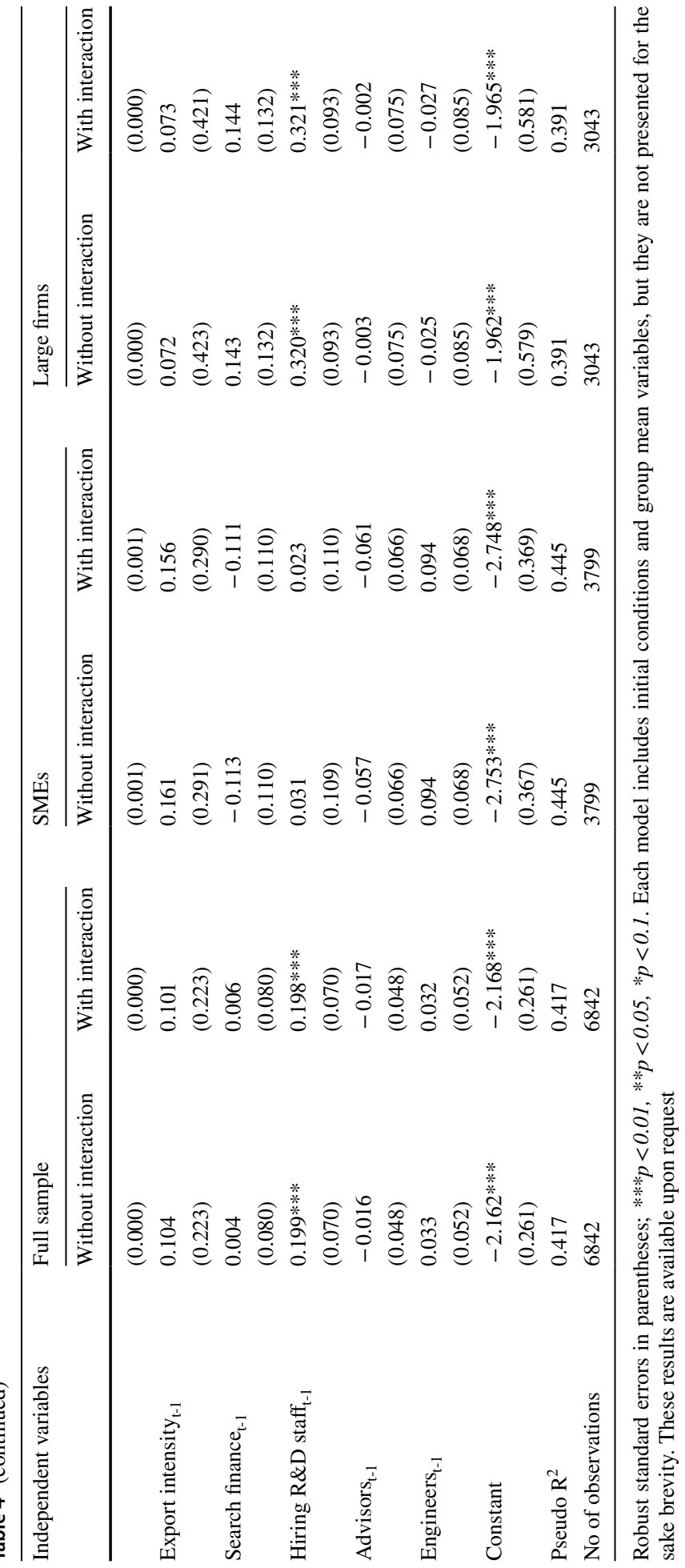




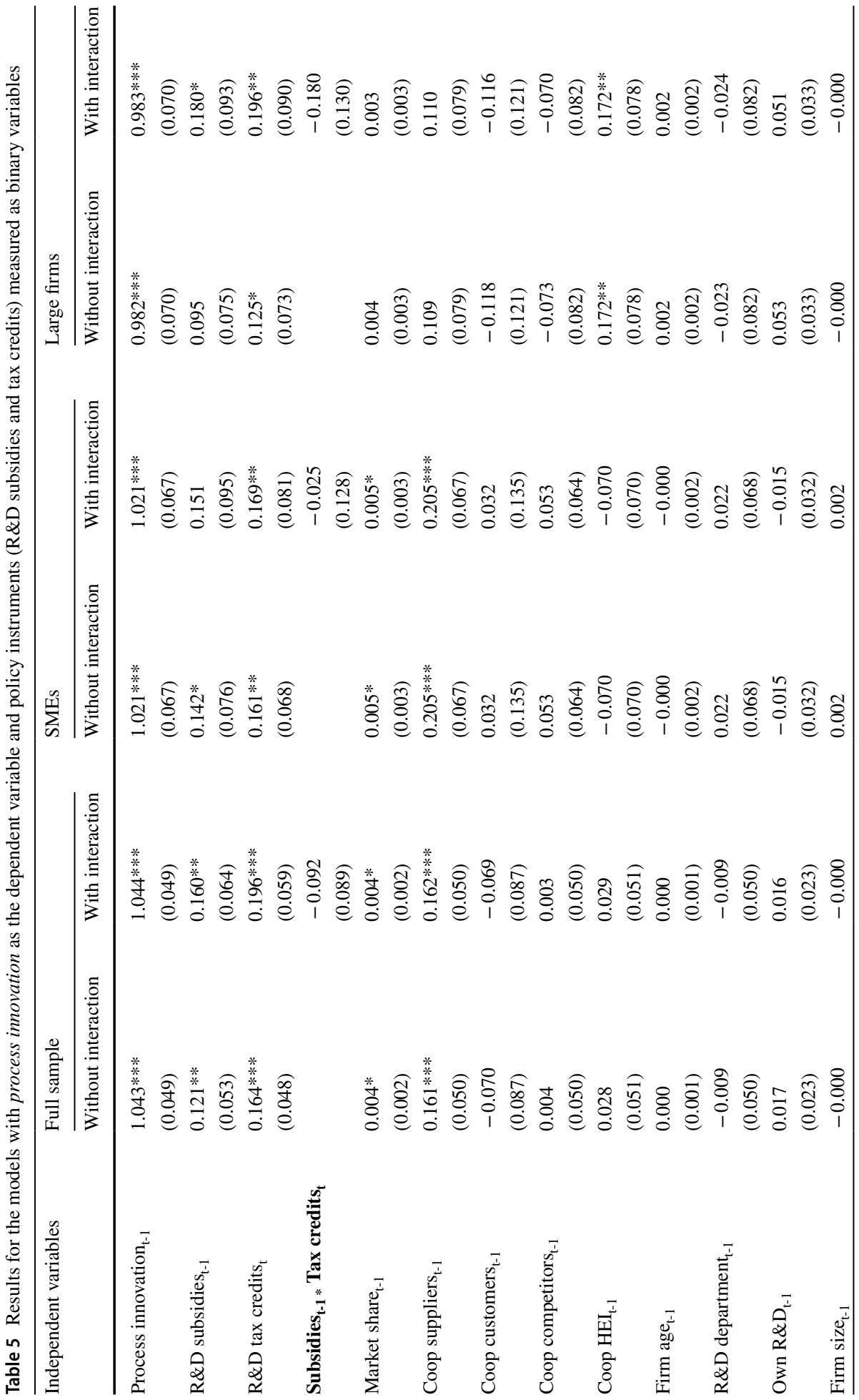




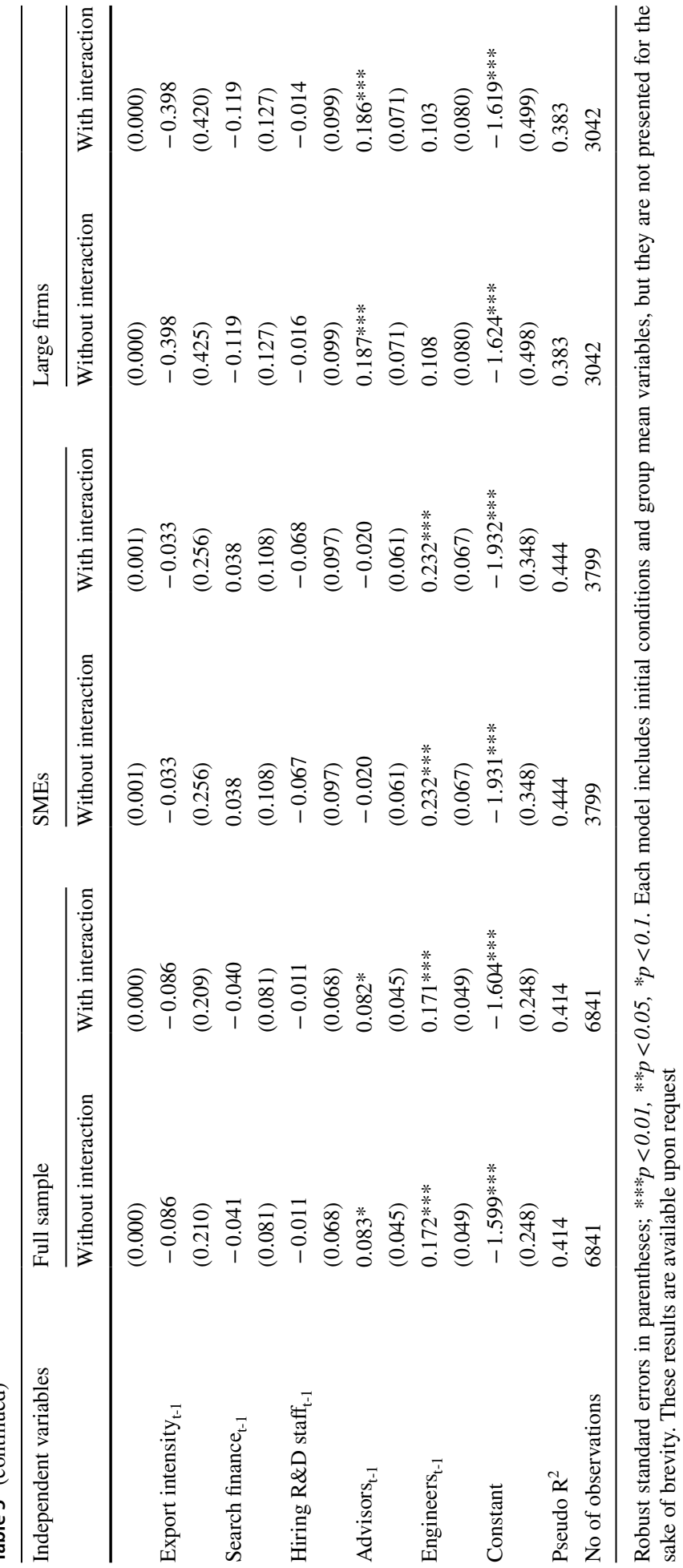


check includes the estimation using a linear probability model (LPM) without firm fixed effects (Tables S8-S11). The third robustness check is the estimation of panel Fixed Effects (FE) models (Tables S12-S15). Empirical results from three types of robustness checks are qualitatively the same as the main results.

\section{Conclusions and policy implications}

This study explores the interplay between two key policy instruments and their individual and joint impacts on product and process innovations in Spanish manufacturing firms. To account for two pertinent issues-innovation persistence and endogeneity of public support, we estimate a dynamic probit model. In addition, to explore whether the magnitude of public support might produce different policy effects compared to the propensity of public support, we report two sets of models, with continuous variables of interest and with binary measures. We report five main findings.

First, we found no evidence of the joint impact of R\&D subsidies and R\&D tax credits. ${ }^{12}$ This suggests that the instrument policy mix, although theoretically assumed to be complementary, in practice is absent. As noted in Sect. 3.2, all three potential outcomes (complementarity, substitution and no interaction) can be expected in empirical policy evaluations, given that innovation policies are not coordinated. Our empirical findings could arise from a policy coordination failure due to the lack of coordination between isolated government departments that design and implement related policies (Dumont, 2017; Magro et al., 2014). Although the potential substitutability occurs at the firm level, managers of firms might not be aware of this or might not be concerned with this. That is, managers would use available government support if their firm is eligible for it, regardless of its potential substitution effect on a firm's innovation performance. On the other hand, government agencies often conduct internal or external impact evaluations, to explore whether a particular government intervention achieves an intended goal. Applied in the case of the policy mix, it means that policy instruments introduced to stimulate firm's innovation performance should be complementary, otherwise adding a new policy instrument to the existing set of instruments is not effective, i.e. a new policy instruments, in combination with existing instruments, does not increase innovation performance.

Consequently, if substitutability is due to a failure in policy coordination, then policy coherence and coordination should theoretically result in the optimal policy mix. This is indeed currently in the focus of policy makers (Flanagan \& Uyarra, 2016). However, it should be pointed out that policy coordination, when achieved, might not produce expected results, because innovation policy is a dynamic, evolutionary process that entails changes in policy goals, rationales and instruments. The reality of conducting a contemporary innovation policy is so complex that policy coordination and a consequent theorized complementary effect might not materialize in practice (Flanagan \& Uyarra, 2016).

Second, our findings indicate a uniformly positive and, with respect to the magnitude, the highest impact of the past innovation activities on the present engagement in product and process innovations. In other words, although our models control for a large number of internal and external factors that can affect product and process innovations, by far the

\footnotetext{
${ }^{12}$ The only exception is the sample of large firms in Table 4 (with product innovation as the dependent variable and dummy policy variables). However, the substitution effect reported in the table is only marginally significant (at the $10 \%$ significance level), so we do not attempt to interpret it as a finding with relevant policy implications.
} 
largest influence is found with respect to true state dependence. Furthermore, we find a strong evidence of spurious state dependence given the positive impact of initial engagement in product and process innovations on their current adoption. Overall, if we take the first and second results together, although the findings are not optimistic in terms of the hypothesized policy mix, the evidence of strong path as well as past dependence provides valuable insights to policy makers on how to continue supporting Spanish manufacturing firms. If firms that have a potential to innovate are supported by public funding, it will give them a significant impetus to continue innovating.

Third, in comparing our results across SMEs and large firms, our main results regarding the lack of the joint policy instrument effects and strong persistence of innovation are qualitatively the same for both firm size categories. The only significant difference between them is reported with respect to control variables and initial conditions related to $R \& D$ subsidies (highly significant for SMEs and insignificant for large firms, Tables 2 and 4). Therefore, public support should encourage start-ups and SMEs, by providing support for increasing their innovative capabilities and to lessen their financial constraints to start innovating. Once these categories of firms begin to innovate, the largest positive effect on the likelihood of innovation will come from path dependence.

Fourth, comparison of results across types of innovation (product versus process) again reveals very similar results concerning the variables of interest and the magnitude of true state dependence. Differences arise when we look at the impact of control variables, including initial conditions. Here we want to comment on the difference in the impact of initial innovation activities on their current probability. Namely, while the magnitude of true state dependence (i.e. path dependence) is statistically the same for both product and process innovations, the magnitude of initial conditions is statistically larger for product than for process innovation (in terms of latter, it is even insignificant in large firms). This suggests that past dependence is stronger for product than for process innovations.

Fifth, our study is among the first to estimate the impact of both propensity and intensity of receiving direct and indirect support. While our main results about the lack of their joint impact and a strong persistence in innovation are confirmed with respect to both measures of public support (binary and continuous), the key differences are highly significant impact of $R \& D$ subsidies and much larger coefficients on R\&D tax credits in the case when propensity rather than intensity of these policy instruments is accounted for. These findings provide some policy implications. If policy makers want to encourage firms to begin innovating, then the provision of public support to firms with a potential for innovation might have a strong policy effect. However, increasing the amount of public support to firms that are already innovating might not produce optimal results.

The results obtained question the effectiveness of the supply side policy instruments i.e. R\&D subsidies and R\&D tax credits for enhancing Spanish economy's innovation performance. The EU Innovation scoreboard classifies Spain in the group of moderate innovators, ${ }^{13}$ despite relative generosity of supply side instruments compared to other EU countries. To enhance Spanish innovative performance, a "mission" oriented research and innovation should be considered as a complement to the existing innovation policy framework. Innovation-led 'smart' growth requires certain types of long-run strategic investments which in turn require public policies that aim to create markets rather than just

\footnotetext{
13 The gap vis-a-vis the EU average is particularly visible with respect to firms' investment in R\&D and innovation, the number of SMEs introducing product/process and marketing innovation and the number of SME cooperation with other enterprises or institution of innovation (RIO Country Report 2016: Spain, https://rio.jrc.ec.europa.eu/sites/default/files/riowatch_country_report/RIO_CR_ES2016_1.pdf).
} 
'fixing' market and systems failures (Mazzucato, 2016, 2018b). ${ }^{14}$ Because innovation is a collective, cumulative and highly uncertain activity with a long lead time, it requires a specific type of finance. Uncertainty means that finance must be willing to bear high risks; the long-run nature of innovation and its cumulativeness imply that the kind of finance should be patient. By nature, financial returns from investment in innovative activities are not always assured, and it usually takes time before they can materialize (Lazonick \& Petrin, 2018 2018).

Our study has some limitations that can serve as suggestions for future research. First, we do not distinguish between radical and incremental innovations, as information available in our dataset do not provide information about them. Álvarez-Ayuso et al., (2018) note that public grants are particularly appropriate for supporting radical innovation, given the high level of risk that this type of innovation entails. In contrast, tax credits can be used to support incremental innovations, which are characterized by a lower level of risk than radical innovation. Second, we do not report results from a sector analysis. Castellacci \& Lie (2015) argue that this type of analysis provides valuable insights to policy makers on how to avoid "one-for-all-policy" and provide differentiated support to firms operating in sectors at different level of technological development. Third, in terms of external validity, our results can be generalized to other European countries that are moderate innovators, like Spain. Analysis in the context of other countries, at different levels of innovation performance, might produce different results. Fourth, policy evaluators have been limited by the lack of information about the amounts of subsidies in the Community Innovation Survey (CIS), the main large-scale survey used in innovation studies (Dimos \& Pugh, 2016). If the amounts of subsidies would be included in the CIS questionnaire, the community of policy evaluators could build a body of empirical evidence on this issue, for the purpose of the comparison of results and evidence-based policy making. Finally, our analysis is focused on R\&D performing firms. Based on descriptive statistics, these firms are older and larger. Future studies could analyse for instance, gazelles, as young, innovative and fast-growing small firms.

\section{Appendix 1}

See Table 6.

\footnotetext{
14 A government can provide the means to focus on research, innovation and investment in novel and uncertain projects "far from the market" resulting in positive spillovers across many sectors, or, in case of SMEs, supporting potentially innovative companies that face barriers to innovate.
} 


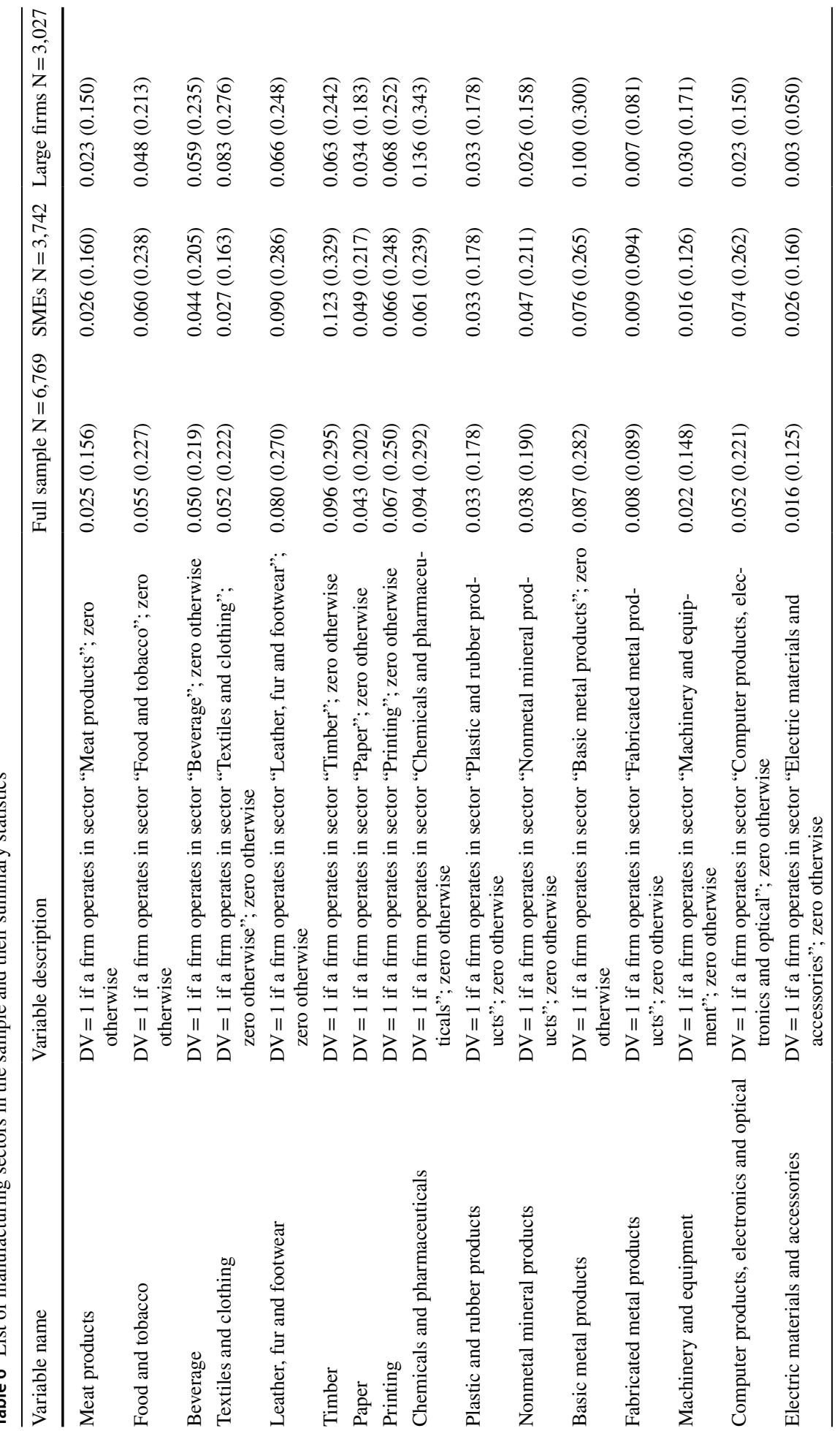




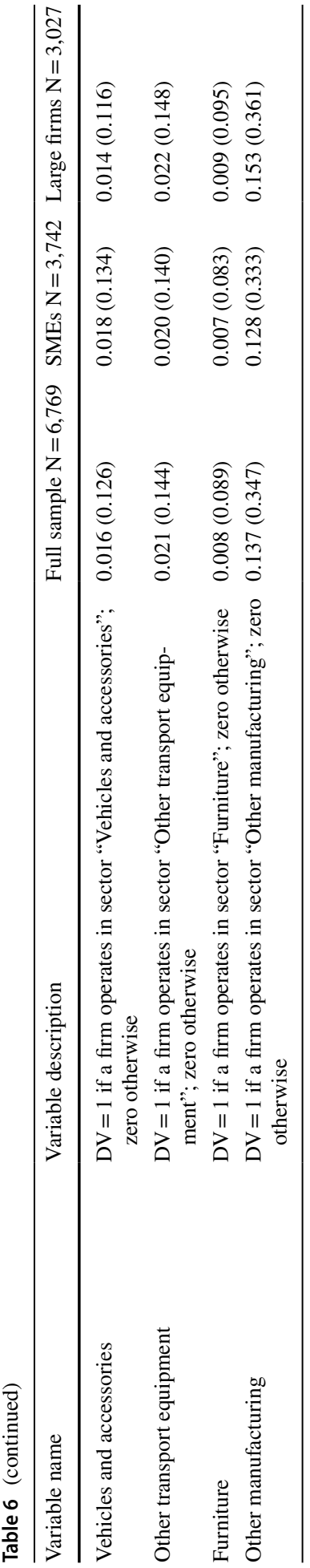

Springer 
Supplementary Information The online version contains supplementary material available at https://doi. org/10.1007/s10961-021-09908-8.

Open Access This article is licensed under a Creative Commons Attribution 4.0 International License, which permits use, sharing, adaptation, distribution and reproduction in any medium or format, as long as you give appropriate credit to the original author(s) and the source, provide a link to the Creative Commons licence, and indicate if changes were made. The images or other third party material in this article are included in the article's Creative Commons licence, unless indicated otherwise in a credit line to the material. If material is not included in the article's Creative Commons licence and your intended use is not permitted by statutory regulation or exceeds the permitted use, you will need to obtain permission directly from the copyright holder. To view a copy of this licence, visit http://creativecommons.org/licenses/by/4.0/.

\section{References}

Álvarez-Ayuso, I. C., Kao, C. \& Romero-Jordán, D. (2018). Long run effect of public grants and tax credits on R\&D investment: A non-stationary panel data approach. Economic Modelling, 75, 93-104.

Antonelli, C., Crespi, F., \& Scellato, G. (2012). Inside innovation persistence: New evidence from Italian micro-data. Structural Change and Economic Dynamics, 23(4), 341-353.

Antonelli, C., Crespi, F., \& Scellato, G. (2013). Internal and external factors in innovation persistence. Economics of Innovation and New Technology, 22(3), 256-280.

Appelt S., Bajgar, M., Criscuolo, C. \& Rueda, F. (2016). R\&D tax incentive: the evidence on design, incidence and impact. OECD Science, Technology and Industry Policy Papers No. 32. OECD Publishing, Paris.

Arnold, E. (2004). Evaluating research and innovation policy: A systems world needs systems evaluation. Research Evaluation, 13(1), 3-17.

Aschhoff, B., \& Sofka, W. (2009). Innovation on demand-Can public procurement drive market success of innovations? Research Policy, 38(8), 1235-1247.

Atkinson, R. D. (2007). Expanding the R\&E tax credit to drive innovation competitiveness and prosperity. Journal of Technology Transfer, 32, 617-628.

Ayllón, S., \& Radicic, D. (2019). Product innovation, process innovation and export propensity: Persistence, complementarities and feedback effects in Spanish firms. Applied Economics, 51(3), 3650-3664.

Baghana, R., \& Mohnen, P. (2009). Effectiveness of R\&D tax incentives in small and large enterprises in Québec. Small Business Economics, 33, 91-107.

Berubé, C., \& Mohnen, P. (2009). Are firms that received R\&D subsidies more innovative? Canadian Journal of Economics, 42(1), 206-225.

Boekholt, P. (2010). The Evolution of Innovation Paradigms and Their Influence on Research, Technological Development and Innovation Policy Instruments. In R., Smits, S., Kuhlmann, and P., Shapira (Ed.), The Theory and Practice of Innovation Policy - An International Research Handbook, (pp. 333-359). Cheltenham: Edward Elgar.

Bronzini, R., \& Piselli, P. (2016). The impact of R\&D subsidies on firm innovation. Research Policy, 45(2), 442-457.

Busom, I., Corchuelo, B., \& Martinez-Ros, E. (2017). Participation inertia in R\&D tax incentive and subsidy programs. Small Business Economics, 48, 153-177.

Busom, I., Corchuelo, B., \& Martínez-Ros, E. (2014). Tax incentives... or subsidies for business R\&D? Small Business Economics, 43, 571-596.

Cassiman, B., \& Veugelers, R. (2006). In search of complementarity in innovation strategy: Internal R\&D and external knowledge acquisition. Management Science, 52(1), 68-82.

Castellacci, F., \& Lie, C. M. (2015). Do the effects of R\&D tax credits vary across industries? A metaregression analysis. Research Policy, 44(4), 819-832.

Clausen, T., Pohjola, M., Sapprasert, K., \& Verspagen, B. (2011). Innovation strategies as a source of persistent innovation. Industrial and Corporate Change, 21(3), 553-585.

Commission, E. (2008). The new SME definition: User guide and model declaration. European Union Publications Office, Brussels.

Cunningham, P., Gök, A., \& Larédo, P. (2016). The Impact of Direct Support to R\&D and Innovation in Firms. In J., Edler, P., Cunningham, A., Gök et al. (eds) Handbook of Innovation Policy Impact 
(Eu-SPRI Forum on Science, Technology and Innovation Policy Series). pp. 54-107. Edward Elgar: Cheltenham.

Cunningham, P., Edler, J., Flanagan, K., \& Laredo, P. (2016). The innovation policy mix. In J., Edler, P., Cunningham, A., Gök et al. (eds) Handbook of Innovation Policy Impact (Eu-SPRI Forum on Science, Technology and Innovation Policy Series). pp. 505-542. Edward Elgar: Cheltenham.

Czarnitzki, D., \& Delanote, J. (2015). R\&D policies for young SMEs: Input and output effects. Small Business Economics, 45(3), 465-485.

Czarnitzki, D., \& Delanote, J. (2017). Incorporating innovation subsidies in the CDM framework: Empirical evidence from Belgium. Economics of Innovation and New Technology, 26(1-2), 78-92.

Czarnitzki, D., Hanel, P., \& Rosa, J. M. (2011). Evaluating the impact of R\&D tax credits on innovation: A microeconometric study on Canadian firms. Research Policy, 40, 217-229.

Czarnitzki, D., \& Hussinger, K. (2018). Input and output additionality of R\&D subsidies. Applied Economics, 50(12), 1324-1341.

Czarnitzki, D., \& Lopes-Bento, C. (2013). Value for money? New microeconometric evidence on public R\&D grants in Flanders. Research Policy, 42, 76-89.

David, P., Hall, B., \& Toole, A. (2000). Is public R\&D a complement or substitute for private R\&D? A review of the econometric evidence. Research Policy, 29(4-5), 497-529.

Dechezleprêtre, A., Einiö, E., Martin, R., Nguyen, K.T. \& Van Reenen, J. (2016). Do tax incentive for research increase firm innovation. An R\&D design for R\&D. National Bureau of Economic Research. Working Paper No. 22405. Cambridge, MA.

Del Río, P. (2014). On evaluating success in complex policy mixes: The case of renewable energy support schemes. Political Science, 47(3), 1-21.

Dimos, C., \& Pugh, G. (2016). The effectiveness of R\&D subsidies: A meta-regression analysis of the evaluation literature. Research Policy, 45(4), 797-815.

Dosi, G. (1990). Finance, innovation and industrial change. Journal of Economic Behavior \& Organization, 13(3), 299-319.

Dumont, M. (2017). Assessing the policy mix of public support to business R\&D. Research Policy, 46, 1851-1862.

Elschner, C., Ernst, C., Licht, G., \& Spengel, C. (2011). What the design of an R\&D tax incentive tells about its effectiveness: A simulation of R\&D tax incentives in the European Union. Journal of Technology Transfer, 36, 233-256.

Engel, D., Eckl, V., \& Rothgang, M. (2019). R\&D funding and private R\&D: Empirical evidence on the impact of the leading-edge cluster competition. Journal of Technology Transfer, 44, 1720-1743.

European Commission (2009). European Innovation Progress Report 2009. Pro Inno Europe paper No. 7.

Flaig, G., \& Stadler, M. (1998). On the dynamics of product and process innovations: A bivariate random effects probit model. Jahrb. Nationalökonomie Statistik, 217, 401-417.

Flanagan, K., \& Uyarra, E. (2016). Four dangers in innovation policy studies-and how to avoid them. Industry and Innovation, 23(2), 177-188.

Flanagan, K., Uyarra, E., \& Laranja, M. (2011). Reconceptualising the 'policy mix' for innovation. Research Policy, 40(5), 702-713.

Foreman-Peck, J. (2013). Effectiveness and efficiency of SME innovation policy. Small Business Economics, 41(1), 55-70.

Freitas, I. M. B. (2007). New instruments in innovation policy: The case of the department of trade and industry in the UK. Science and Public Policy, 34(9), 644-656.

Ganter, A., \& Hecker, A. (2013). Persistence of Innovation: Discriminating between Types of Innovation and Sources of State Dependence. Research Policy, 42, 1431-1445.

González, X., \& Pazó, C. (2008). Do public subsidies stimulate private R\&D spending? Research Policy, 37(3), 371-389.

Guo, D., Guo, Y., \& Jiang, K. (2016). Government-subsidized R\&D and firm innovation: Evidence from China. Research Policy, 45(6), 1129-1144.

Grimpe, C., \& Kaiser, U. (2010). Balancing internal and external knowledge acquisition: The gains and pains from R\&D outsourcing. Journal of Management Science, 47(8), 1483-1509.

Grotti, R., \& Cutuli, G. (2018). xtpdyn: A community-contributed command for fitting dynamic randomeffects probit models with unobserved heterogeneity. Stata Journal, 18, 844-862.

Guerzoni, M., \& Raiteri, E. (2015). Demand-side vs. supply-side technology policies: Hidden treatment and new empirical evidence on the policy mix. Research Policy, 44, 726-747.

Guisado-González, M., González-Blanco, J., Coca-Pérez, J. L., \& Guisado-Tato, M. (2018). Assessing the relationship between $R \& D$ subsidy, $R \& D$ cooperation and absorptive capacity: An investigation on the manufacturing Spanish case. Journal of Technology Transfer, 43, 1647-1666. 
Hajivassiliou, V., \& Savignac, F. (2011). Novel approaches to coherency conditions in ldv models with an application to interactions between financing constraints and a firms decision and ability to innovate. LSE discussion papers 36 .

Haned, N., Mothe, C., \& Nguyen-Thi, T. U. (2014). Firm persistence in technological innovation: The relevance of organizational innovation. Economics of Innovation and New Technology, 23(5-6), 490-516.

Henningsen, M. S., Hægeland, T., \& Møen, J. (2015). Estimating the additionality of R\&D subsidies using proposal evaluation data to control for research intentions. Journal of Technology Transfer, 40, $227-251$.

Hervas-Oliver, J.-L., Garrigos, J. A., \& Gil-Pechuan, I. (2011). Making sense of innovation by R\&D and non-R\&D innovators in low technology contexts: A forgotten lesson for policymakers. Technovation, $31,427-446$.

Hervas-Oliver, J. L., Sempere-Ripoli, F., Boronat-Moll, C., \& Rojas, R. (2015). Technological innovation without R\&D: Unfolding the extra gains of management innovations on technological performance. Technological Analysis and Strategic Management, 27, 19-38.

Hottenrott, H., \& Lopes-Bento, C. (2016). R\&D partnerships and innovation performance: Can there be too much of a good thing? Journal of Product Innovation Management, 2016(33), 773-794.

Howlett, M., How, Y. P., \& del Rio, P. (2015). The parameters of policy portfolios: Verticality and horizontality in design spaces and their consequences for policy mix formulation. Environment and Planning c: Government and Policy, 33, 1233-1245.

Huang, C., Arundel, A., \& Hollanders, H. (2010). How firms innovate: R\&D, non-R\&D, and technology adoption. UNU- MERIT Working Paper No. 2010-027.

Huergo, E., Trenado, M., \& Ubierna, A. (2016). The impact of public support on firm propensity to engage in R\&D: Spanish experience. Technological Forecasting and Social Change, 113, 206-219.

Hwang, Y.-S., Hwang, M.-H., \& Dong, X. (2015). The relationships among firm size, innovation type and export performance with regards to time spans. Emerging Markets Finance and Trade, 51(5), 947-962.

Ichimura, H., \& Taber, C. (2001). Propensity-score matching with instrumental variables. The American Economic Review, 91(2), 119-124.

Imbens, G. W., \& Wooldridge, J. M. (2009). Recent developments in the econometrics of program evaluation. Journal of Economic Literature, 47(1), 5-86.

Klette, T. J., Moen, J., \& Griliches, Z. (2000). Do subsidies to commercial R\&D reduce market failures? Microeconometric Evaluation Studies, Research Policy, 29(4-5), 471-495.

Krzeminska, A., \& Eckert, C. (2016). Complementarity of internal and external R\&D: Is there a difference between product versus process innovations? R\&D Management, 46(S3), 931-944.

Lach, S. (2002). Do R\&D subsidies stimulate or displace private R\&D? Evidence from Israel. Journal of. Industrial Economics, 50(4), 369-390.

Lazonick, W., \& Petrin, T. (2018). Innovative Enterprise and Sustainable, Inclusive Growth: A Policy Agenda. ISIGrowth Working Paper 4/2018, January, http://www.isigrowth.eu/2018/08/01/innov ative-enterprise-and-sustainable-inclusive-growth-a-policy-agenda/

Le Bas, C., \& Scellato, G. (2014). Firm innovation persistence: A fresh look at the frameworks of analysis. Economics of Innovation and New Technology, 23, 423-446.

Magro, E., Navarro, M., \& Zabala-Iturriagagoitia, J. M. (2014). Coordination-Mix: The hidden face of STI policy. Review of Policy Research, 31(5), 367-389.

Magro, E., \& Wilson, J. R. (2013). Complex innovation policy systems: Towards an evaluation mix. Research Policy, 42(9), 1647-1656.

Magro, E., \& Wilson, J. R. (2018). Policy-mix evaluation: Governance challenges from new place-based innovation policies. Research Policy, 48(10), 103612.

Marin, G. (2014). Do eco-innovations harm productivity growth through crowding out? Results of an extended CDM model for Italy. Research Policy, 43, 301-317.

Marino, M., Lhuillery, S., Parrota, P., \& Sala, D. (2016). Additionality or crowding-out? An overall evaluation of public R\&D subsidy on private R\&D expenditure. Research Policy, 45, 1715-1730.

Martin, B. R. (2016). R\&D policy instruments- a critical review of what we do and don't know. Industry and Innovation, 23(2), 157-176.

Martínez-Ros, E., \& Labeaga, J. M. (2009). Product and process innovation: Persistence and complementarities. European Management Review, 6(1), 64-75.

Mazzucato, M. (2016). From market-fixing to market-creating: A new framework for economic policy. Industry and Innovation, 23(2), 140-156.

Mazzucato, M. (2018a). Mission-oriented innovation policies: Challenges and opportunities. Industrial and Corporate Change, 27(5), 803-815. 
Mazzucato, M. (2018b). The challenges and opportunities of framing the EC 2020 'challenges' as 'mission-oriented' policies. ISIGrowth Policy Brief no. 3, May 2018. http://www.isigrowth.eu/2018/ 05/27/mission-oriented-innovation-policy-challenges-and-opportunities

Meissner, D., \& Kergroach, S. (2021). Innovation policy mix: Mapping and measurement. Journal of Technology Transfer, 46, 197-222.

OECD (2010). The Innovation Policy Mix. In: OECD Science, Technology and Industry Outlook 2010, pp. 251-279. Paris: OECD Publishing.

OECD (2014). Tax incentives for R\&D and innovation. In: OECD Science, Technology and Industry Outlook 2014, pp. 164-173. Paris: OECD Publishing.

OECD (2019). R\&D Tax Incentives: Spain, 2018. Directorate for Science, Technology and Innovation. Paris: OECD Publishing.

Peters, B. (2009). Persistence of innovation: Stylized facts and panel data evidence. Journal of Technology Transfer, 34(2), 226-243.

Petrin, T. (2018). A Literature Review on the Impact and Effectiveness of Government Support for R\&D and Innovation. ISIGrowth Working Paper 5/2018. http://www.isigrowth.eu/2018/02/14/a-literaturereview-on-the-impact-and-effectiveness-of-government-support-for-rd-and-innovation/.

Pless, J. (2021). Are "Complementary Policies" Substitutes? Evidence from R\&D Subsidies in the UK. Available https://ssrn.com/abstract=3379256 or https://doi.org/10.2139/ssrn.3379256

Polder, M., van Leeuwen, G., Mohnen, P., \& Raymond, W. (2010). Product, process and organizational innovation: drivers, complementarity and productivity effects. MPRA Paper No. 23719.

Radicic, D., \& Balavac, M. (2019). In-house R\&D, external R\&D and cooperation breadth in Spanish manufacturing firms: Is there a synergistic effect on innovation outputs? Economics of Innovation and New Technology, 28(6), 590-615.

Radicic, D., \& Pinto, J. (2019). Collaboration with External organizations and technological innovations: evidence from spanish manufacturing firms. Sustainability, 11(9), 2479.

Radicic, D., \& Pugh, G. (2017). R\&D programmes, policy mix, and the "European Paradox": Evidence from European SMEs. Science and Public Policy, 44(4), 497-512.

Radicic, D., Pugh, G., Hollanders, H., Wintjes, R., \& Fairburn, J. (2016). The impact of innovation support programmes on SME innovation in traditional manufacturing industries: An evaluation for seven EU regions. Environment and Planning C: Government and Policy, 34(8), 1425-1452.

Revest, V., \& Sapio, S. (2012). Financing technology-based small firms in Europe: What do we know? Small Business Economics, 39(1), 179-205.

Romero-Jordán, D., Delgado-Rodríguez, M. J., Álvarez-Ayuso, I., \& de Lucas-Santos, S. (2014). Assessment of the public tools used to promote R\&D investment in Spanish SMEs. Small Business Economics, 43, 959-976.

Rouvinen, P. (2002). Characteristics of product and process innovators: Some evidence from the Finnish innovation survey. Applied Economics Letters, 9(9), 575-580.

Santamaría, L., Nieto, M. J., \& Barge-Gil, A. (2009). Beyond formal R\&D: Taking advantage of other sources of innovation in low- and medium-technology industries. Research Policy, 38(3), 507-517.

Schmidt, T. S., \& Sewerin, S. (2019). Measuring the temporal dynamics of policy mixes-an empirical analysis of renewable energy policy mixes' balance and design features in nine countries. Research Policy, 48(10), 103557.

Schmiedeberg, C. (2008). Complementarities of innovation activities: An empirical analysis of the German manufacturing sector. Research Policy, 37(9), 1492-1503.

Sterlacchini, A., \& Venturini, F. (2019). R\&D tax incentives in EU countries: Does the impact vary with firm size? Small Business Economics, 53, 687-708.

Sutton, J. (1991). Sunk Costs and Market Structure. United States: Massachusetts Institute of Technology (MIT) Press.

Tassey, G. (2007). Tax incentives for innovation: Time to restructure the R\&E tax credit. Journal of Technology Transfer, 32, 605-615.

Tavassoli, S., \& Karlsson, C. (2015). Persistence of various types of innovation analyzed and explained. Research Policy, 44(10), 1887-1901.

Testa, G., Szkuta, K., \& Cunningham, P. N. (2019). Improving access to finance for young innovative enterprises with growth potential: Evidence of impact of R\&D grant schemes on firms' outputs. Research Evaluation, 28(4), 355-369.

Torugsa, N. A., \& Arundel, A. (2013). Private-public collaboration and innovation performance: Does training matter? International Journal of Innovation Management, 17, 1340011.

Triguero, A., \& Córcoles, D. (2013). Understanding innovation: An analysis of persistence for Spanish manufacturing firms. Research Policy, 42(2), 340-352. 
Un, C. A., \& Asakawa, K. (2015). Types of R\&D collaborations and product innovation: The benefit of collaborating upstream in the knowledge chain. Journal of Product Innovation Management, 32, $138-153$.

Uyarra, E. (2010). What is evolutionary about 'regional systems of innovation'? Implications for regional policy. Journal of Evolutionary Economics, 20, 115-137.

Wallsten, S. J. (2000). The effects of government-industry r\&d programs on private r\&d: the case of the small business innovation research program. RAND Journal of Economics, 31(1), 82-100.

Wen, L., \& Maani, S. A. (2019). Job mismatches and career mobility. Applied Economics, 51(10), 1010-1024.

Wooldridge, J. M. (2005). Simple solutions to the initial conditions problem for dynamic, nonlinear panel data models with unobserved heterogeneity. Journal of Applied Econometrics, 20, 39-54.

Wooldridge, J. M. (2010). Econometric Analysis of Cross Section and Panel Data. Second edition. Cambridge, Massachusetts: MIT Press.

Publisher's Note Springer Nature remains neutral with regard to jurisdictional claims in published maps and institutional affiliations. 